\title{
الطبيعة القانونية للمسؤولية المدنية عن أضرار \\ الروبوتات (دراسة تحليلية هقارنة)
}

\author{
بجاث مفرم الى مؤَثر \\ الجوانب القانونيتّوالاقتصاديت للذكاء الاصطناعي \\ وتصكنولوجيا المعلومات \\ 每 \\ كليتتالحقوق- جامعتمالمنصورة مايو
}

shel

أ.د / محمد ربيع أنور فتع الباب

أستاذ القانون المدني المساعد المديد

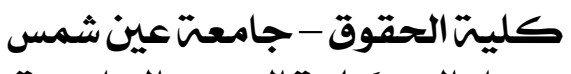

ومعار إلى كليتة البريمي الجامعيتية

بسلطنتة عمان 
تقام هذه الورقة البحثية دراسة تحليلية مقارنة في الطبيعة القانونية للمسؤولية

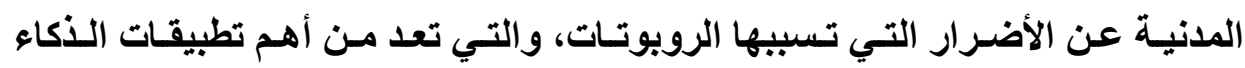

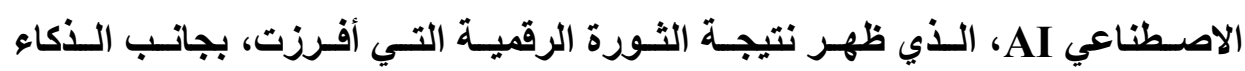
الاصطناعي، نتائج أخرى، هي: إنترنت الأثشياء، والبيانات الضخمة.

وقد ركزت هذه الورقة على محاولة البحث في الطبيعة القانونية للمسؤولية

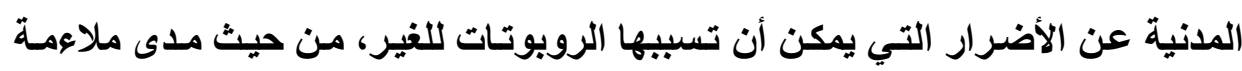

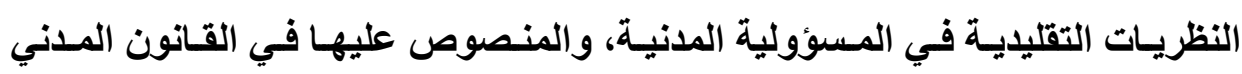

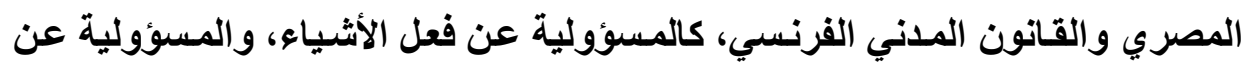

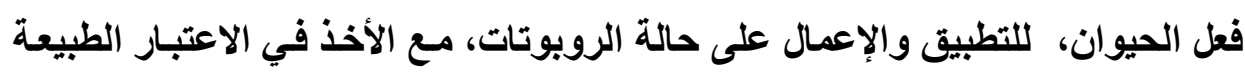

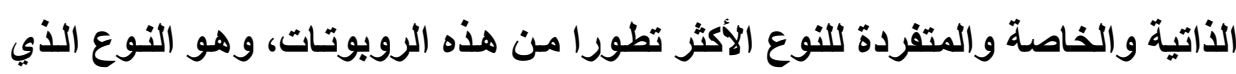
يتمتع بدرجة كبيرة من الاستقلالية في اتخاذ القرارات، وفق مـا تفرضه ولهن عليه ملابسات

$$
\text { وظروف المحيط الخارجي. }
$$

وقد كان لزامًا عند البحث في الطبيعة القانونية للمسؤولية المدنية عن الأضرار

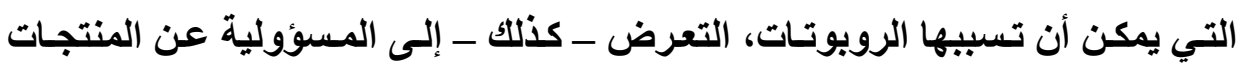

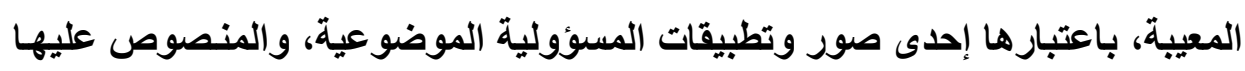

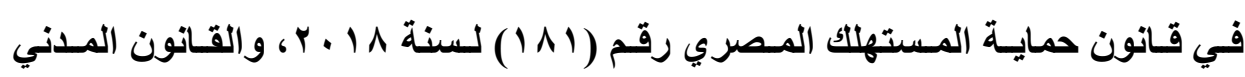
الفرنسي.

غير أن البحث في الطبيعة القانونية للمسؤولية المدنية عن الأضرار التي يمكن

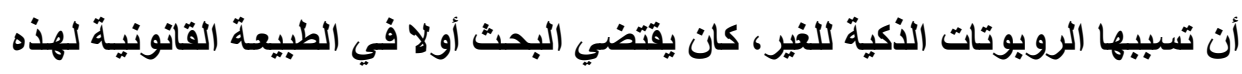

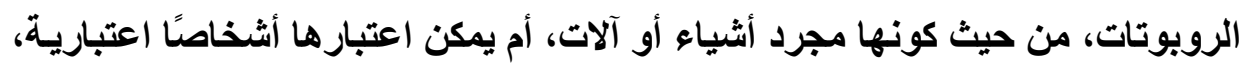




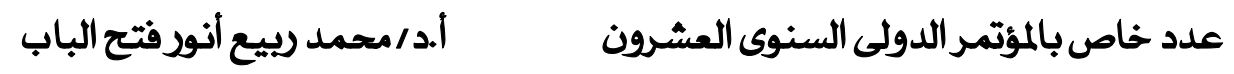

على غرار الثركات والجمعيات والهيئات، أم أنه يجب الاعتراف لها بشخصيةٍ قانونية مستحدثة، هي الثخصية القانونية الرقمية؟.

وقد خلصت الار اسـة إلى صعوبة الاعتراف ـ في الوقت الحسلي- بالروبوتـات

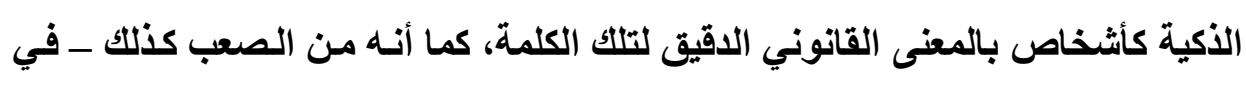
الوقت الراهن - استحداث شخصية قانونية جديدة لها، والإبقاء من ثم على اعتبارهـا مجرد أشياء منقولة، لها طبيعتها الخاصة والمتفردة، مع فتح الباب لإمكانية الاعتراف القانوني لها مستقبلا بشخصيةٍ رقميةٍ

كما انتهت الاراسة إلى أن إمكانية إقرار نظريـة المسؤولية الموضوعية، التي

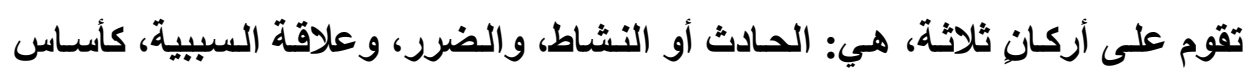

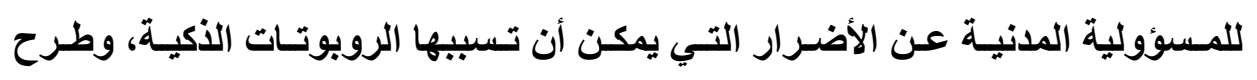

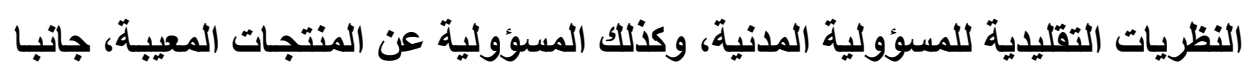
من نطاق المسؤولية المدنية عن أضرار الرويوتـات الأكية، مـع تأهب مشرعي دول

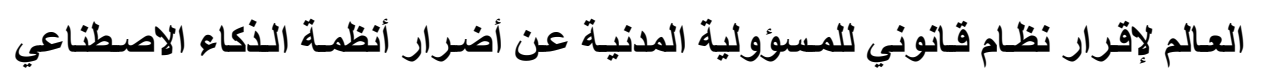

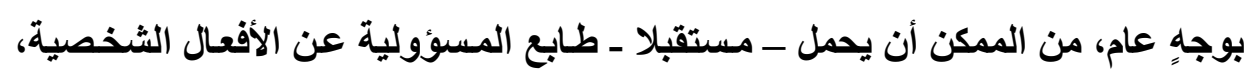

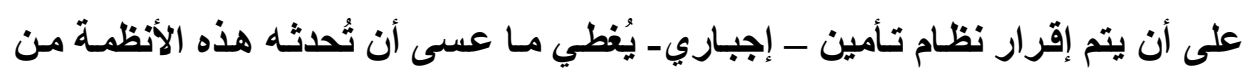
أخطار يترتب عليها أضرارٌ تصيب الغير. 


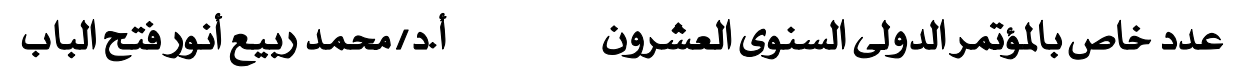

\section{الاقدمهة}

كان للثورة الرقمية التي اجتاحت العالم في الآونـةِة الأخيرة، بصورها الثُلاث:

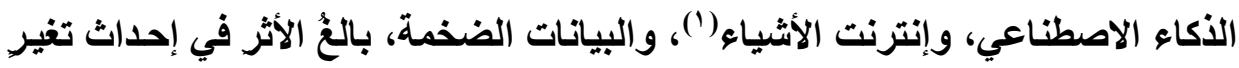
هائل في مختلف المجالات، كالمجال الاقتصادي والمجال الاجتمـاعي والمجال العسكري ومجـال النقل والمواصـلات ومجـال التعليم ومجـال الصحة، وأيضًا المجـال القـانوني، وتغير المفاهيم التقليدية بهذه المجالات، بصورةٍ أدت إلى إحداث ثورةٍ تقتيةٍ داخل جميع

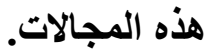

ونتلقف من هذه الصور الثلاث للثورة الرقمية، الأكاءَ الاصطناعي، الذي يتمثل

في نظام كمبيوتر يتمتع بقرات تضاهي قدرات الإنسان. ووفق خبير الأكاء الاصطناعي "Jean-Gabriel Ganascia" فيان الذكاء الاصطناعي يتكون من مجموعة من العمليات التي تنفذ بواسطة آلة، وتحتاج إلى ذكاء()، الأمر الذي يفوح بمضمونه عن

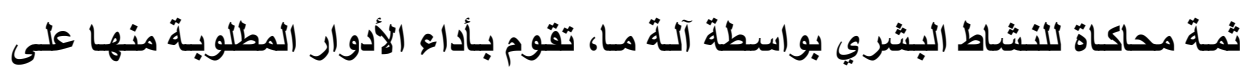
غرار ما يُطلب من الإنسان البشري.

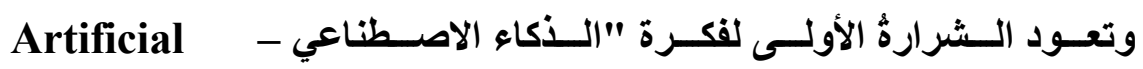

-Intelligence

(')- DOSQUET (E), DOSQUET (F.), MOYSAN (Y.), et SCIBETTA (F.): L' internet des objets et la data, L.G.D.J., 2018, P. 7 et s.

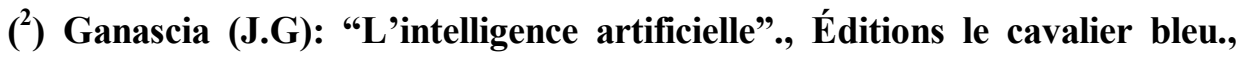
2007., p.9; Cité par: El Kaakour (N.): “ L'intelligence artificielle et la responsabilité civile délictuelle"., Université Libanaise., Faculté de droit et des sciences politiques et administratives filière francophone., 2017., p.1. 


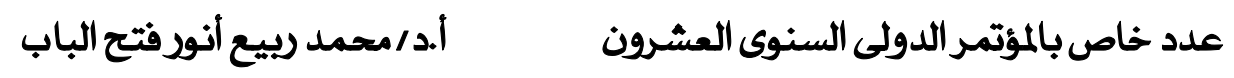

Alan Turing يمكن استخدامه لإثبات أن الآلة تتمتع بالأكاء.

وحدثت الولادة الحقيقيـةُ للذكاء الاصطناعي في العـام 909 1، عن طريـق

علماء الرياضيات: "جون مكارثي - John McCarthy"، و "مارفن لي مينسكي"، و "ناثانيلروشستر"، و"كلود شانون"، وذلك عندما قدموا ورقة علمية متعلقة بالذكاء الاصطناعي، في مـؤتمر "دارتمـوث"، المنعقد في كليـة دارثمـوت بالولايـات المتحدة

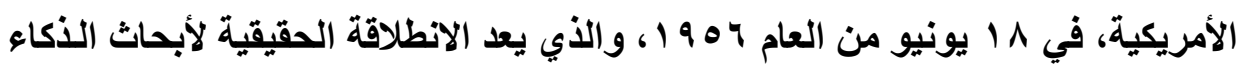
(الاصطناعي (')

وتتنوع تطبيقاتُ الأكاعِ الاصطناعي المستخدمة في العديد من المجالات، مثل:

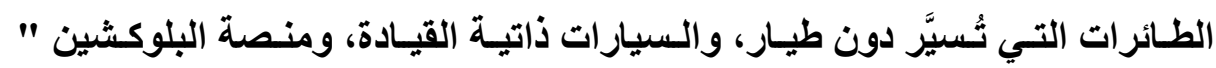
Blockchain العـلات الرقميـة، وإبـرام العقود ذاتيـة التنفيذ، والتـي يُطلق عليهـا مجـازا اصطلاح "العقود الذكيـة -Smart Contracts"(†)، وكذلك الروبوتـات الذكيـة، التي تعمل بذاتيـة واستقلالية عن الإنسان البشري، بحيث تستطيع التعامل مـع البيئة الخارجيـة المحيطة بها من تلقاء نفسها، وبحسب الظروف والملابسات المختلفة.

ويعد علمُ الإنسان الآلي أو الروبوت أحدَ فروع الذكاعِ الاصطناعي الرئيسة، والأي يتألف من: الهندسة الكهربائية والهندسة الميكانيكية وعلوم الحاسب لتصميم

(1) CALO (R.): "Artificial Intelligence Policy, A primer and Roadmap", University of California Davis Law Review, 2017, vol.51, p.397.

( $\left.{ }^{2}\right)$ Schulpen (R.W.H.G): "Smart contracts in the Netherlands- A legal research regarding the use of smart contracts within Dutch contract law and legal framework"., Tilburg University., 2018., P. 8. 


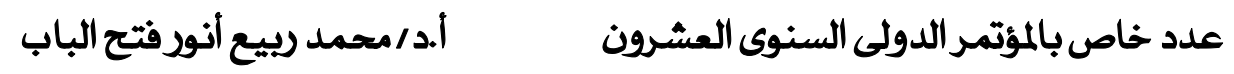

إنسان آلي أو رويوت، والذي بموجب نظام الأكاء الاصطناعي يستطيع أن يقوم بجميع التصرفات التي يقوم بها الإنسان البشري، بل وبصورةٍ تفوقه من حيث السرعة وانب والدقة في إنجاز المهام المطلوبة منه.

وعلمُ الروبوتاتِ، كما تعرفه لجنةُ مراجعة أبحاث العلوم والتكنولوجيا الرقمية

Allistene لعسام \& 1 • r (CERNA)، هـو " جميـع المـواد التـي تسـاهم فـي فهـم

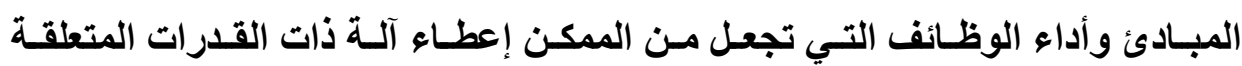
بالإدراك واتخاذ القرار والتفاعل والتكيف مع البيئة الخارجية المحيطة بها، والتي تجمع بين التصميمين: الميكانيكي، والتقني المتعلق بالذكاء الاصطناعي"('). وقد ظهر اصطلاحُ "الروبوت" لأول مرة في التاريخ عندما استعمله الكاتب المسرحي "كاريـل تششابيك "Karel Chapek" (Y)، وكسان ذلــ في مسسرحيته " "رويوتــات ورســوم العالميـة" "Rossumovi univerzàlni Roboti" والمعروفة اختصارًا باسم "R.U.R."، والتي كتبها في العام • ب و 19. وظهرت صناعةُ الإنسان الآلي أو الروبوت بالمعنى الحقيقي لهذه الكلمـة في

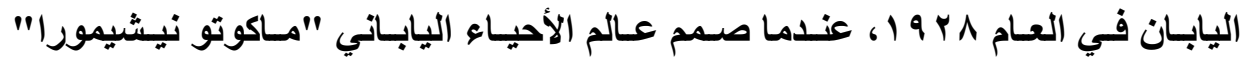
الروبـوت الآلـي "Gakutensoku" في مدينـة أوسـاكا اليابانيـة، والذي كـان يمكنـه تحريك وجهه ورأسه ويديه عن طريق آلية ضغط الهواء، ألا أنـه فقد أثنـاء جولـة في ألمانيا في ثلاثينيات القرن العشرين(")

(1) $<<$ Éthique de la recherche en robotique $>>$., Rapport no 1 de la CERNA., novembre 2014., p.54; Citè par: El Kaakour Nour., op.cit., p. 6.

(1) https://ar.wikipedia.org/wiki تثــــــــ/

(2) https://www.wikipedia.org/wiki/Gakutensoku 


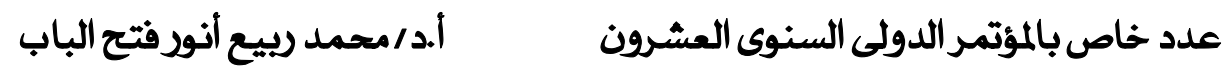

ولعل أهم مثـال حي يطالعنـا بـه الواقـعُ العملـي للروبوتـات الأكيـة، الروبـوت

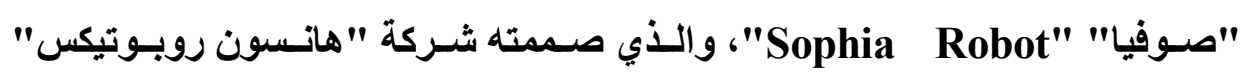
ومديرها الدكتور "ديفيد هانسون"، الموجودة في هونج كونج في 9 أبريـل عـام

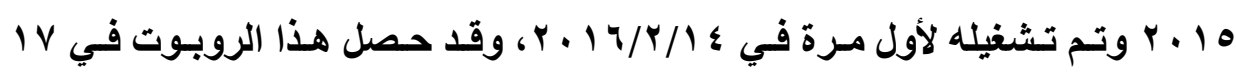

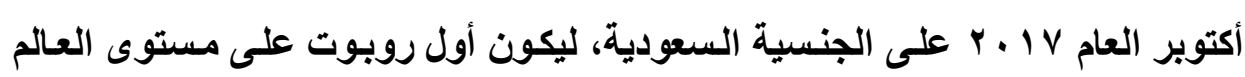

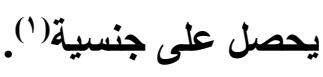

\section{أولا: أهـهية هوضوع الدراسة}

يكتسب موضوعُ الدراسةِ أهمية بالغة من ناحيتين؛ الأولىى: عملية أو واقعية،

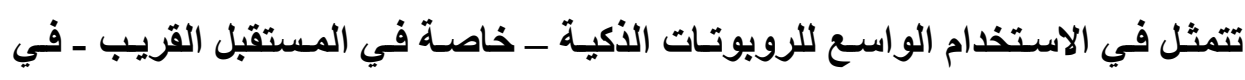

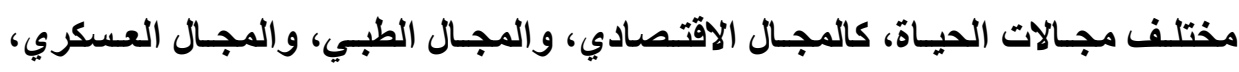

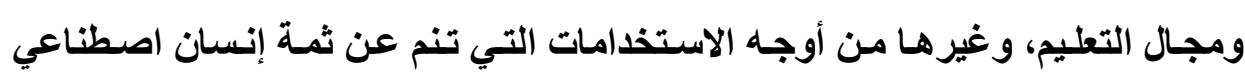
يتمتع بذكاء يضاهي الأكاء البشري، وما قد يترتب على ذلكك من أضرار تتسبب فيها هذه الروبوتات، سواء للبشر أم للأموال.

والثانيـة: قانونيـة، تتمثل في عدم وجـود تنظيم تشريعي يعـالج المسؤولية

المدنية عن الأضرار التي تسببها الأنظمة الإكترونية أو الرقمية بصفةٍ عامة، والأنظمة

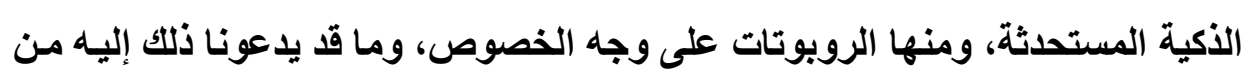

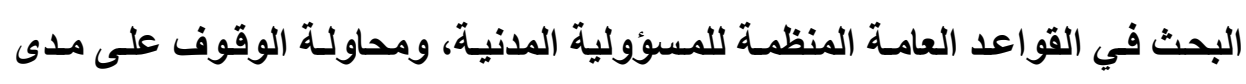
إمكانية إسقاطها على الروبوتات من عدمـه، أم البحث في قواعد قانونية جديدة تنظم المسؤولية المدنية عن الأضرار التي تسببها الرويوتـات، ومـا يتطلبه ذلك من البحث

(") https://www.ar.wikipedia.org> صوفيا - (رويوت) . 


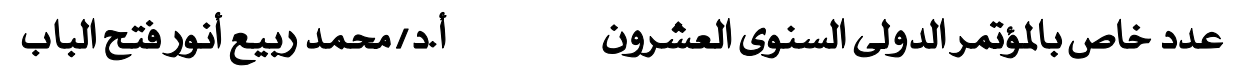

بداعة في مسألة الطبيعة القانونية للروبوت، من حيث كونـه: شيئا أم شخصنًا بـالمعنى القانوني الاقيق، أم أن طبيعته الذاتية والمتفردة قد تفرض علينـا التوجه نحو ضرورة إقرار شخصية قانونية مستحدثة خاصة به. ثانياً: إشكالية الدراسة

تـدور الإثـكالية المحوريـة للار اسـة حـول البحـث في إطـار قـانوني يحكـم

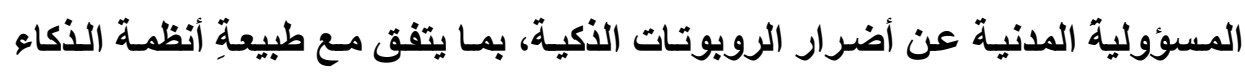

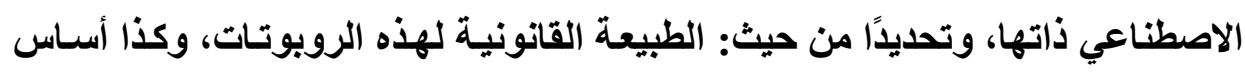
المسؤولية المدنية عن الأضرار التي يُمكن أن تُحدثها للغير. ويتفرع من تلك الإثكالية الرئيسة العديذُ من التساؤلات، لعل من أهمها: - ما هو أسـاس المسؤولية المدنية عن الأضرار التي يمكن أن تسببها الروبوتـات

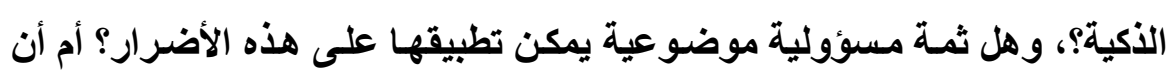

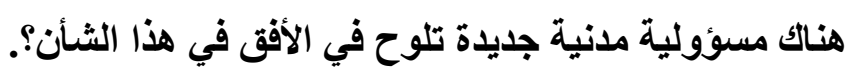

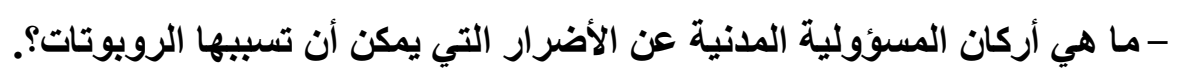

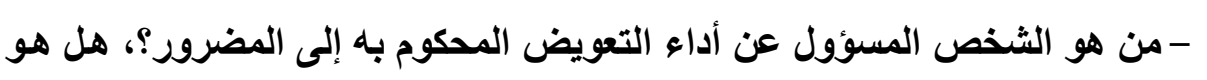
المنتج أو المُصنع أم المبرمج أو المطور أم المستخدم؟. - مــاهي الطبيعـة القانونيـة للروبـوت؟، وهـل يمكـن اعتبـاره مـن قبيـل الأثـياء المنقولة؟، أم من قبيل الأشخاص الاعتبارية؟، أم أن طبيعته الذاتية تجعله لا يقبل أن يندرج تحت عباءة أي من هذين المفهومين؟.

ثالثا: منهمبية الدراسة لغاية معالجة الإثكالية الرئيسة المتقدمة لموضوع الدراسة، والإجابة عما سبق طرحه من تساؤلات بالار اسـة، رأيت اتباع منهجين بحثيين، الأول: المنهج التحليلي، 


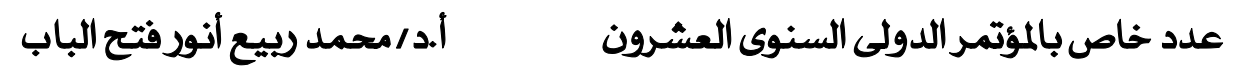

لأجل تحليل النصوص القانونية المتضمنة لقواعد عامـة في شـأن المسؤولية المدنية، والبحث في مدى إمكانية إنز الها على موضوع الاراسـة، وكذا تحليل الأحكام القضائية

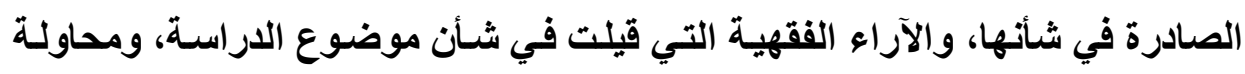

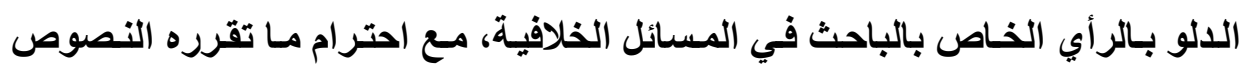
القانونية من قواعدٍ عامة في هذا الثأن.

والثاني: المنهج المقارن بين القانون المصري والقانون الفرنسي، وتحديدًا فيما

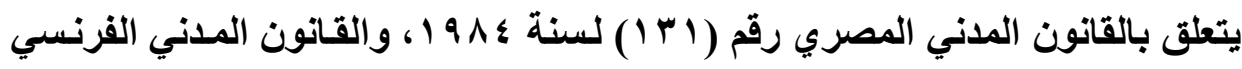

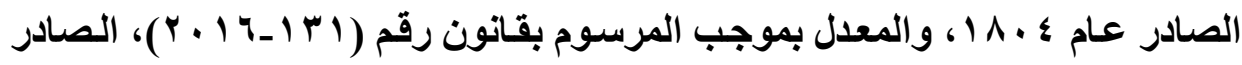

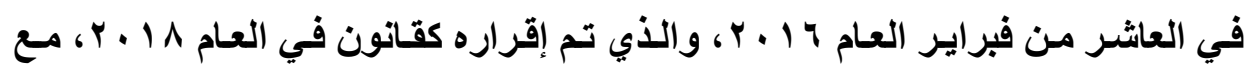

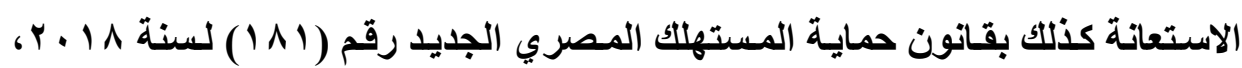

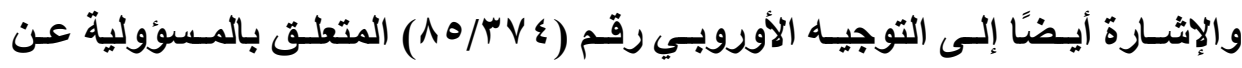

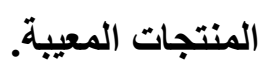

\section{رابعا: خطة الدراسة}

بناءً على ما تقلم عرضه، وبسبب أن الوقوف على أسـاس المسؤولية المدنية

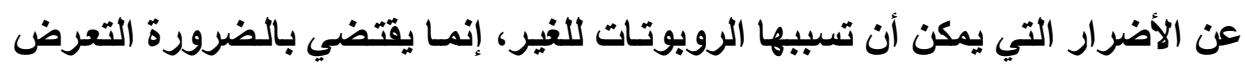
أولا إلى الطبيعة القانونية لهذه الرويوتات، رأيت تقسيم الدراسة على النحو الآتي: المبحث الأول: الطبيعة القانونية للروبوت. المبحث الثاني: أساس المسؤولية المدنية عن أضرار الروبوتات الأكية. 
عدد خاص بالمؤتمر الدولى السنوى العشرون أ.د/محمد ربيع أنور فتح الباب

\section{المبحث الأول}

الطبيعة القانونية للروبوت

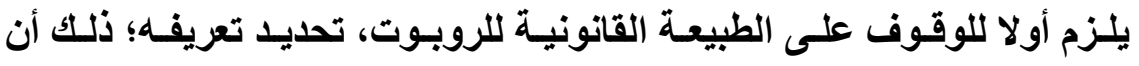

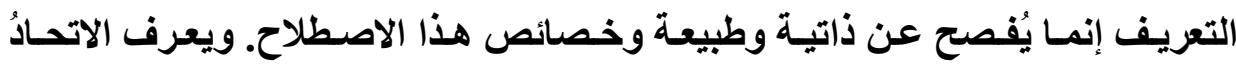

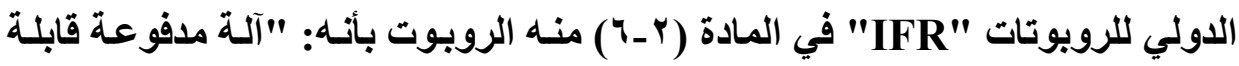

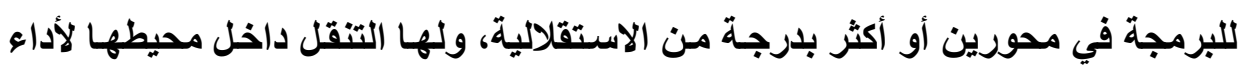

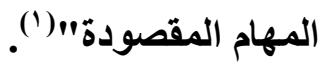

وتعرف دائرة البحوث بالبرلمسان الأوروبي European Parliamentary Research Service "ERPS" التصرف في محيطها، ويمكنها اتخاذ القرار"(").

ومما سبق، نستطيع أن نقف على الطبيعة القانونية للروبوت، ونحللها، عن طريق تقسيم هذا المبحث إلى ثلاثة مطالب، على النحو الآتي:

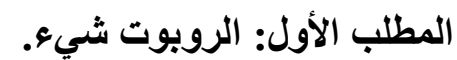
المطلب الثاني: الروبوت شخص. المطلب الثالث: الرأي الخاص في الموضوع.

(1) "A robot is an actuated mechanism programmable in two or more axes with its environment to perform indented tasks". Referred to in: BALKIN (J.M): "The path of Robotics law", California law Review, Vol. 6., June 2015, P. 50.

(2) Referred to in: CINDY (V.R.): "Liability of robots: legal responsibility in cases of errors or malfunctioning", Ghent University, Faculty of Law, 2018 P. 13. 


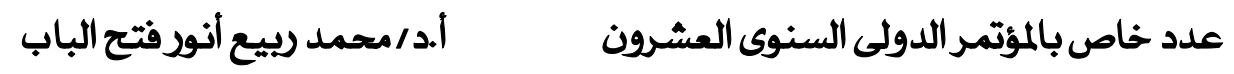

\section{المطاب الأول \\ الروبوت شيs}

يتضح من التعاريف المتقدمة للروبوت، إذا مـا أخذناها بمعناهـا الحرفي، أنسه لا يعدو كونه آلة أو شئيًا. ويقصد بالشيء، كل كائن له ذاتية في الوجود، سواء كان ماديًا

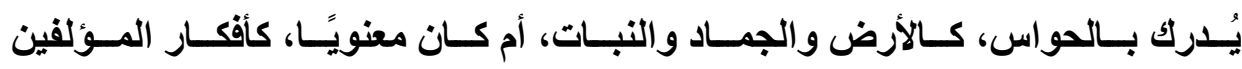
والاختراعات والعلامات التجارية. والثيء المادي يكون محلا للحق العيني، أما الشيء المعنوي، فيكون محلا للحق الشخصي والحق الذهني أو المختلط' '. ويعتبر الروبوت شيئا منقولا؛ إذ يمكن نقله من مكان إلى آخر دون تلف، ومـا

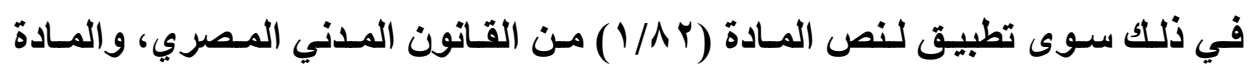
(O ا من القانون المدني الفرنسي. غير أن ما سبق من تحليل إنما نستطيع أن نطبقه فقط على الروبوت التقليدي، ذلك الروبوت الذي لا يقوى على العمل باستقلالية عن الإنسان البشري، بحيث يأخذ

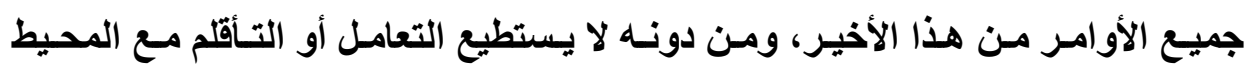

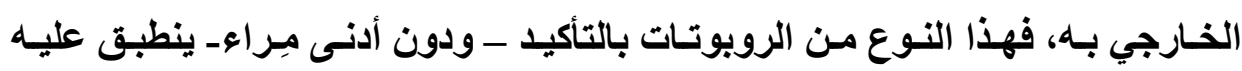

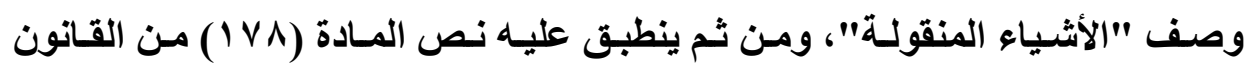
المدني المصري من أن:" كل من تولى حراسة أشياء تتطلب حراستها عناية خاصـة أو

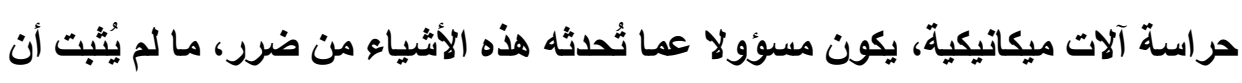

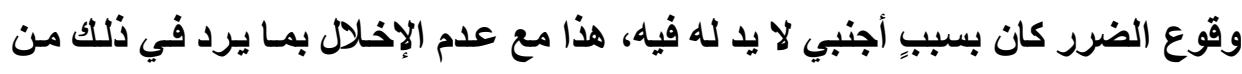

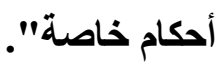
(') د. محمد ربيع فتح البـاب، د. مها رمضان بطيخ، المدخل لاراسـة القانون - نظريـة الحق، دار

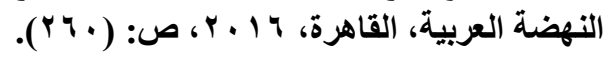




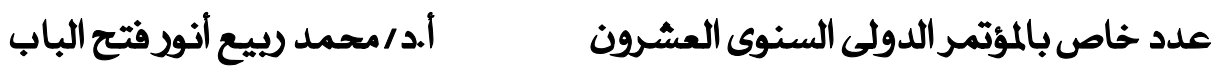

وتفسير ما سبق، هو أن الروبوتات التقليدية تعد من قبيل الآلات الميكانيكية، بل

وفوق ذلك تتطلب حراستها عناية خاصة، ومن ثم يُسأل حارسُُها عن أي ضرر تُسببه للغير، غايـة مـا في الأمـر أنـه يُشترط لقيـام هذه المسؤولية، أن تكون للمسؤول عن

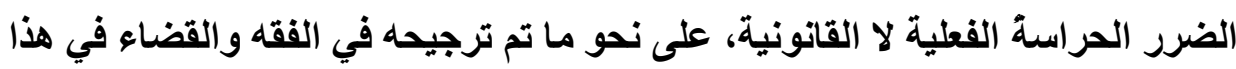

الشأن.

أما فيما يتعلق بالقانون المدني الفرنسي، ونتيجة عدم وجود نصوص خاصـة تحكم المسؤولية عن الأشياء الخطرة أو الآلات الميكانيكية، من بين النصوص القانونية

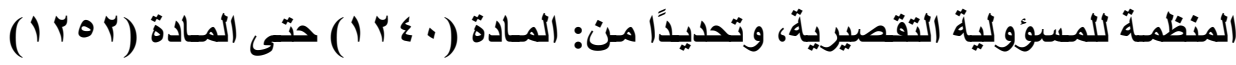
منه، فيمكننا في هذا الصدد تطبيق نوعين من المسؤولية المدنية: النوع الأول: المسؤولية عن الأشياء بصورةٍ عامـة، خطرة كانت أم غير ذلك، والمنصوص عليها في المادة (r \& Y I ) من القانون الفرنسي، من أن الشخص مسؤول ليس فقط عن الضرر الذي يسببه فعله، و إنمـا أيضا عن....... الأثشياء التي بحراسته. غير أن هذا النوع من المسؤولية التقصيرية يشترط أن يثبت المضرور الحراسة الفعلية للشخص على الرويوت التقليدي وقت وقوع الضرر. النوع الثاني: المسؤولية عن المنتجات المعيبة، والمنصوص عليها في المواد

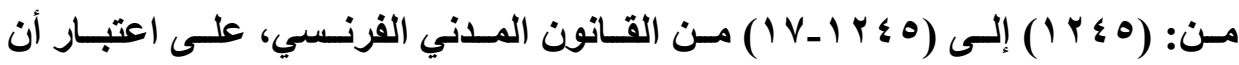
الروبوتات تعد في الأخير من قبيل المنتجات. ويُشترط لإقامة هذا النوع من المسؤولية التقصيرية، وعلى وفق ما تقضي به المادة (0 ؛ ب ا ــ) من القانون المدني الفرنسي، أن يقوم المضرور بإثبات وجود عيب في منتج الروبوت والضرر وعلاقة السببية بين 


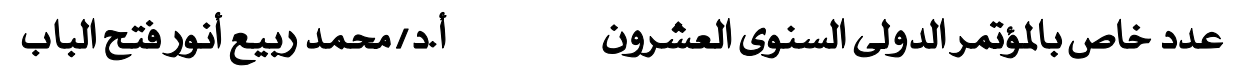

ولا يقدح في إقامـة المسؤولية عن الرويوتـات المعيبة، باعتبار هـا منتجًا، علم

وجود خطأ في تصنيعه أو مطابقته للمعايير أو المقاييس المطلوبـة، أو حصوله على

ترخيص بالعمل، بل أن المسؤولية في هذا الصدد تقوم بمجرد إثبات وجود عيب، حتى

ولو لم ينم هذا العيب عن ثمة خطأ، وما في ذلك سوى تطبيق لنص المـادة (0 ؛ ب 1 ـ 9)

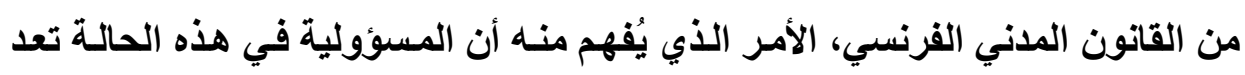
بذاتها مسؤولية موضوعية، يُعفى في ظلها المضرورُ مسن إثبـات ركن الخطأ، ويتم استبداله بركن آخر، هو ركن العيب، أي وجود عيب بالمنتج.

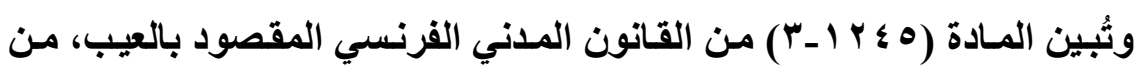

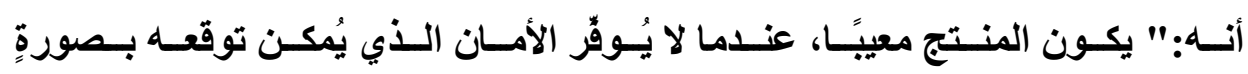

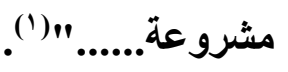

وعودة مرة أخرى إلى الطبيعة القانونية للروبوت، وعلى وفق مـا انتهينـا إليه

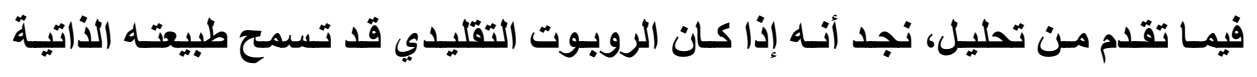
باعتباره شيئا، ممـا ينطبق عليهه وصف الشيء المُقرر في القانون المدني المصري

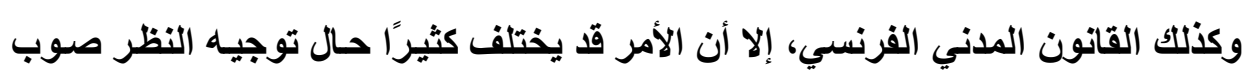

$$
\text { الروبوث الأكي. }
$$

فالروبوتـات الأكية ـ كمـا قدمنا ـ وإن كانت في الأخير لا تعدو سـوى كونهـا

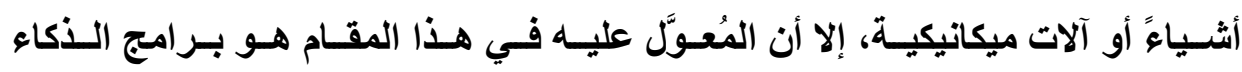
الاصطناعي ذاتها التي تتم تغذيتها بها، لا الإنسان الآلكي، وآيـة ذلك أن تلك الرويوتـات

(1) Art (1245-3):" Un produit est défectueux au sens du présent chapitre lorsqu'il n'offre pas la sécurité à laquelle on peut légitimement s'attendre.........". 


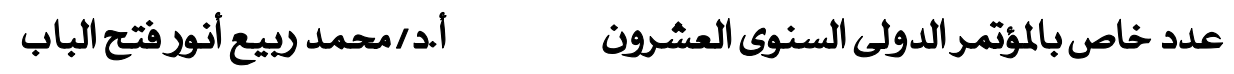

الأكية تستطيع - وبموجب هذه البرامج أو الأنظمـــ العمل من تلقاء نفسها، والتكيف

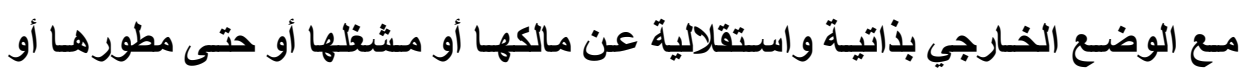

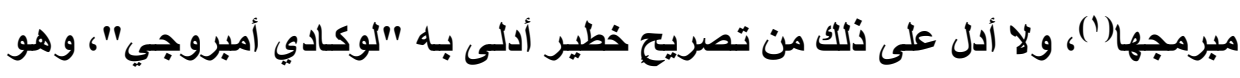

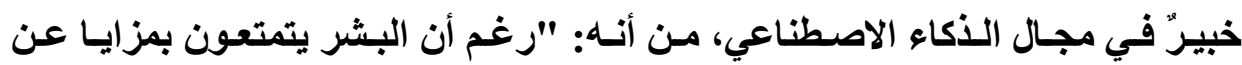
الروبوتـات، مثل: أنهم أكثر ديناميكية وتنوعًا، إلا أن الإكترونيـات الأكيـة يمكن أن تتفوق على البشر في العديد من الوظائف خلال نصف قرن؛ ذلك أنها قد تمتلك وعيًا في

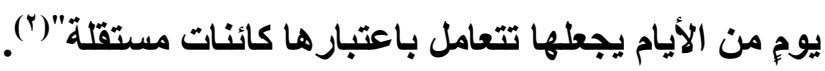
كما حذر بعضُ الخبراءٍ في مجال الأكاء الاصطناعي من أن الرويوتات قد تكون قاتلـة إذا لـم يـتم التحكم فيها بصورةٍ كبيرة مسن قِبل البشر، وإنها قد تكون من أكبر التهديدات الوجودية التي قد يواجهها كوكبُ الأرض(").

فهل رُغم ما تقدم سنستمر في اعتبار الروبوتـات الأكية مجرد آلات أو أشياء؟، تسـاؤل يستحق أن نفرد السطور القادمـة للإجابـة عنـه بشيء مـن التفصيل والتحليل المناسبين للطبيعة الذاتية والمستقلة لهذه الروبوتـات، مع الأخذ في الحسبان نظريـة

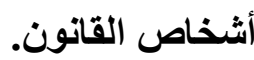

(1) CALO (R.):" Robots in American Law", Legal Studies Research Paper, $n^{\circ}$ 2016-04, SSRN, 2016, p.6 et $s$.

$\left.{ }^{2}\right)$ https://al-ain.com/article/artificial-intelligence-robots-humans-century

(r) https://hrw.org/ar/news/2020/01/03/337058. 


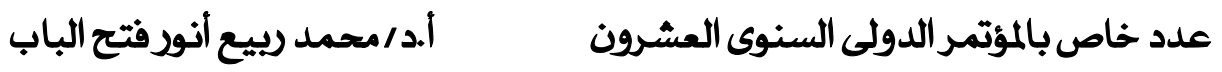

\section{المطلب الثاني}

\section{الروبوت شخص}

أثثيرَ التسـاؤلُ في هـذا المقـام حـول مـدى إمكانيـة اعتبـار الروبـوت مـن قبيـل الأشـخاص، وتحديدًا الأشـخاص الاعتباريـة، ومنحهـا مـن ثم ذات الثخصية القاتونيـة الممنوحة للشخص الاعتباري، على اعتبار أن الروبوت يعد من قبيل الكيانات، شأنه في ذلك شأن الثركات والجمعيات والهيئات.

ونستعيد من الذاكرة القانونية، ونحن بهذا المقام، وفي صدر الإجابة عن هذا

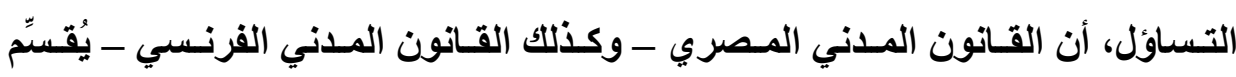
الأشخاص إلى أشخاص طبيعيين وآخرين اعتباريين. والشخص الطبيعي هو الإسسان.

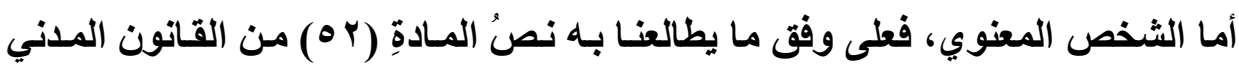
المـصري، هـو الدولـة والمـديريات والمــن.......، والهيئـات، والأوقـاف، والـشركات التجارية والمدنية، والجمعيات والمؤسسات، وكل مجموعة من الأثخاص أو الأموال تثبت لها الشخصيةُ الاعتبارية بمقتضى نص في القانون. وعند هذه الفقرة الأخيرة نقف قليلا، خاصة في ظل عدم وجود نص قانوني يحكم أنظمة الذكاء الاصطناعي بوجهٍ عـام، والروبوتات على وجه الخصوص.

فالمعلوم أن الثخص الطبيعي يتمتع بعدة حقوق أو مميزات تنتج من الاعتراف له بثخصيةٍ قانونية، مثل: الاسم، والموطن، والحالة، والأهلية القانونية، في حين أنسه يصعب توفر هذه الحقوق أو المميزات في الرويوتـات. كمـا أن الأهلية القانونية، والتي تعتبر من مميزات الثخص الطبيعي، لا يتصور توفرها، بمفهومها القانوني الدقيق في الروبوتـات، سواء كاتت أهلية الوجوب Capacité de urissance أم أهلية الأداء 


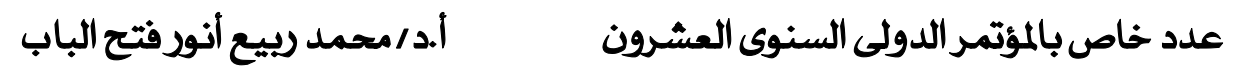

Capacité d'exercise عمرية - زمنية ـ معينة، وهو ما لا يتوفر بالتأكيد في الروبوت.

كذلك، يتمتع الشخصُ الاعتبـاري بالعديد من الحقوق إلا مـا كـان منهـا ملازمًا

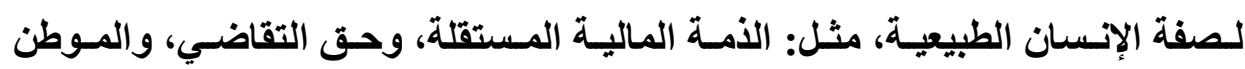
المستقل، وهو ما يصعب كذلك تصور توفره في الروبوتات.

ويُقهم مما تقام أن الروبوتات الأكية لا يمكن اعتبارهـا من قبيل الأشخاص(')،

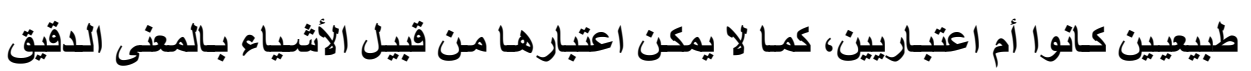
للشيء، لما تقدم عرضه من أسباب.

\section{الاطلب الثالث}

\section{الرأي الخاص في الموضوع}

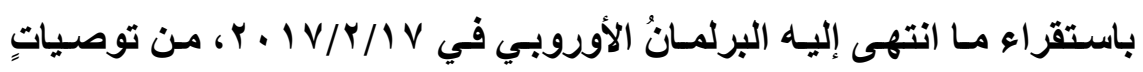

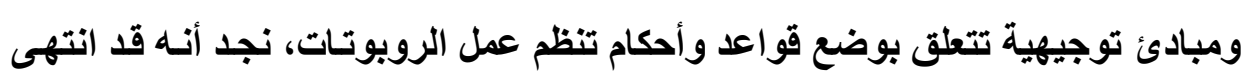
إلى التوصية بالاعتراف بثخصيةٍ قانونية إلكترونية أو رقمية للروبوتات الذكية، والتي توفي

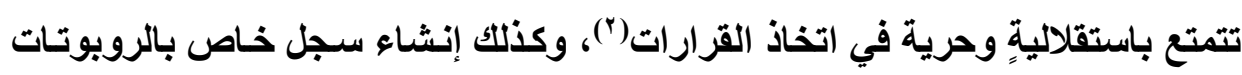

(')NATHALE NEVEJANS: "Le Statut Juridique du Droit du Robot doit-il évoluer?", décembre 2019, https://lajauneetlarouge.com

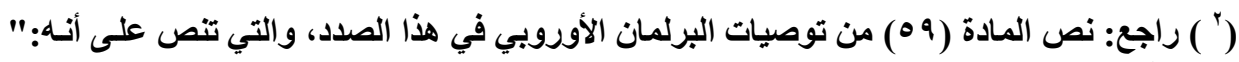

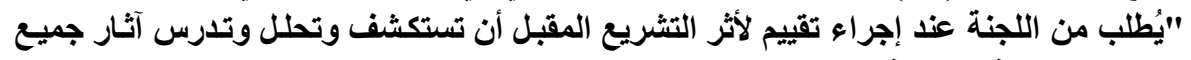

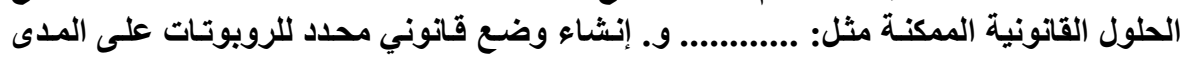

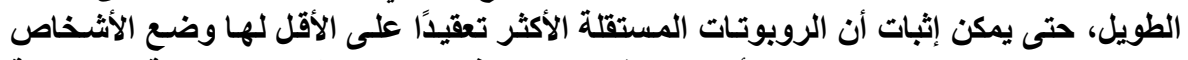

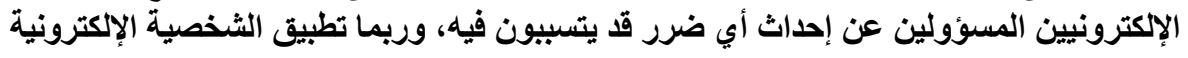

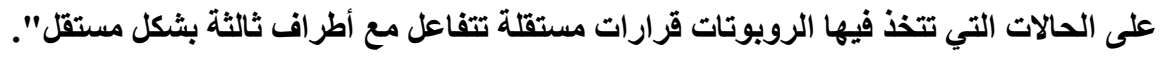


الأكية، تُسجل فيهه جميعُ المعلومـات المتعلقة بكل روبوت، وأيضًا إقرار نظـام خـاص للتـأمين ضــ مخـاطر الروبوتـات، وكذلك صـعوبة تطبيق القواعـ العامـة للمسوؤولية بوضعها الحالي على الأضرار التي تقع بسبب الروبوتات أو أنظمة الذكاء الاصطناعي، الأمسر الذي يُثيـر قدرًا ليس بـالهين مـن الشك والريبـة حول مـدى إمكانيـة استحداث شخصية قانونية للروبوتات الأكية، على غرار الشخصية القانونية الممنوحة للشخص الطبيعي والشخص الاعتباري، وما سيتطلبه ذلك من استحداث نظام قانوني خاص يحكم المسؤولية المدنيـة عن الأضرار التـي تُسببها أنظمـة الذكاء الاصطناعي بوجـهٍ عـام، ومنها الرويوتات الأكية.

وأرى أنه يصعب تطبيق ما تقدم ذكره من تصور على الأقل في الوقت الحالي؛

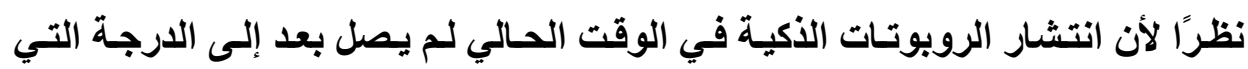

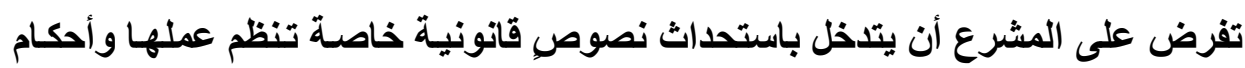

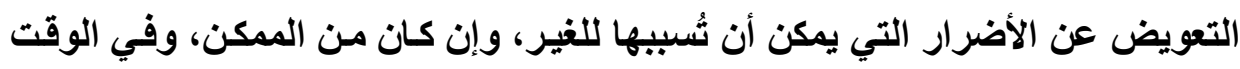

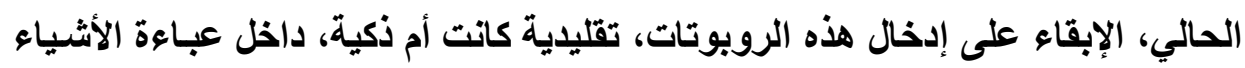

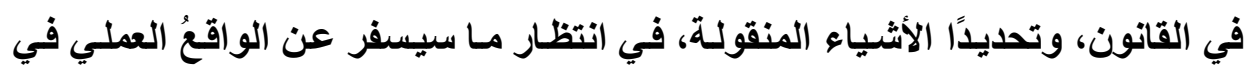
المستقبل من زيادة الأدوار التي تقوم بها الروبوتات الأكية في مختلف مجالات الحياة، وطبيعة تلك الأدوار.

زد على ذلـك، أن مـنح الروبوتـات الشخصية القانونيـة سـيؤدي إلى تقليـل أو

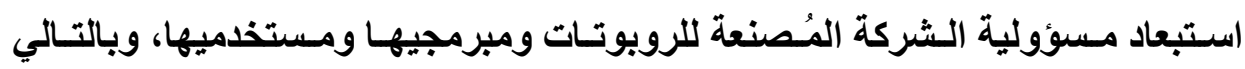
ستكون الروبوتات أكثر خطرًا وأقل دقة في التصنيع؛ لأن استبعاد أو تقليل مسؤولية

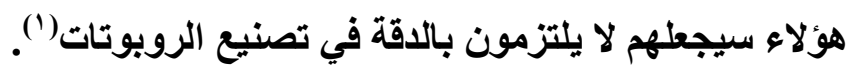

(1) CHONÉ (A.S.), et GLASER (P.H.): Résponsabilité Civile du Fait du Robot doné d' intelligence Artificielle: Faut-il créer une personnalité robotique?, CCC, $n^{\circ}$ 1, Janvier 2018. 


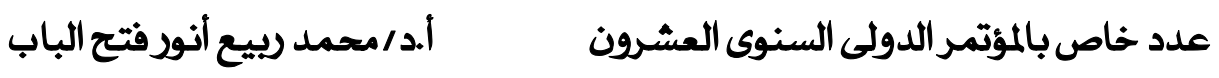

ولا يقداح في سـبيل محاولـة إقامـة بنيـان يعترض مـا انتهينـا إليـه مسن إدخـال

الروبوتات الأكية داخل عباءة الأثياء باصطلاحها المنصوص عليه في المـادة ( V^)

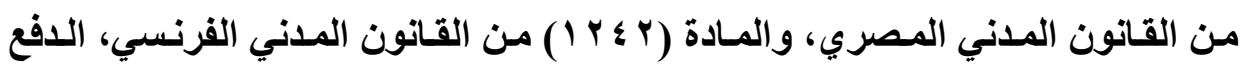
بالصفة غير الماديـة لبرامج الذكاء الاصطناعي بوجهٍ عـام، ومنهـا البرامج التي يتت تغذية الروبوتات بها؛ ذلك أن هذه البرامج بمجرد أن توضـع على دعامـة رقميـة، فإنها تكتسب الصفة المادية، ومن ثم ينطبق عليها وصفُ الأشياء بمعناه المقصود في هـاتين المادتين.

وثُدعم تحليلنا السابق بـالحكم الصادر عن محكمة الدرجة الأولى ببـاريس من

أن:" الصورة القابلة للاستـساخ والحفظ، تُعتبر شيئا يندرج في إطـار مفهوم المسادة

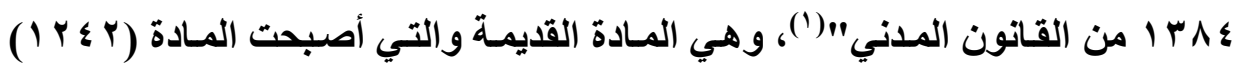

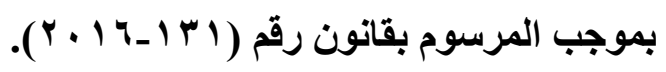

وعلى وفق هذا الحكم، يمكن أن نستنتج أن الصورة غير المحفوظة لا تعتبر شيئا، إلا إذا تم تجسيدها في دعامةٍ إلكترونية، وهو ما ينطبق بالقياس على المعلومـات والبيانات المتعلقة بالذكاء الاصطناعي، والتي يتم تجسيدها أو تخزينها على دعامـات تُشكل في الأخير برامج أو أنظمة ــمؤتمتة_ للأكاء الاصطناعي.

وننوه أخيرًا إلى أمر مهم أيضًا في هذا المقام، دفع به البعض لقياسه على حالة

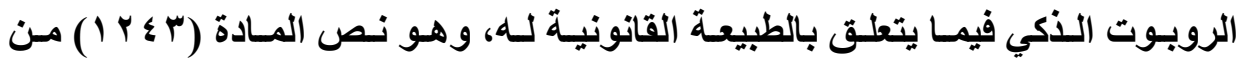
القانون المدني الفرنسي، من أن:" صاحب الحيوان أو من يستخدمه أثنـاء استخدامه، مسئول عن الضرر الذي أحدثه الحيوان، سواء كـان الحيوان في حراسته أو ضل أو

(1) Cité par: Danjaume (G.): “ La responsabilité du fait de l'information”., J.C.P.G., no 1., 1996., 


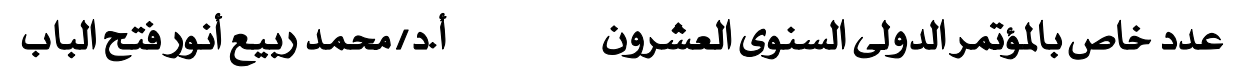

تشرب"، إذ حاول البعض(') الدفع بهذا النص لأجل تثبيه الروبوت بـالحيوان، ومن ثم إقامـة المسؤولية المدنية عن الأضرار التي يسببها للغير على أسـاس من نص هذه

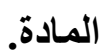

غيـر أنتــا لا نتفـق مـع هــا الـرأي؛ ذلــك لوجـود اخـتلاف ذاتـي بـين الحيـوان

والرويوت؛ فالحيوان يعد في الأخير كائنًا حيًا، يتمتع بالإحساس على الرغم من فقدانـه

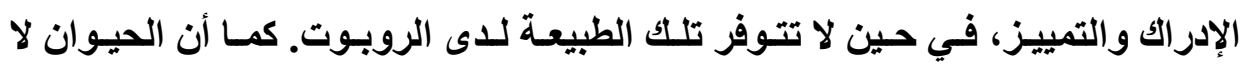

يستطيع - في جميع الأحوال - اتخاذ القرارات التي تتناسب مع كل موقف يتعرض لهله، بعكس الروبـوت الـذكي؛ الـذي، بفضل مـا يتمتـع بـه مسن ذكساء اصـطناعي، يستطيع فعل ذلك.

(1) Mendoza-Caminade (A.): “ Le droit confronté à l'IA des robots: vers l'émergence de nouveaux concepts juridiques?"., Recueil Dalloz., no 8., 2016., p.445; Cité par: El Kaakour Nour., op.cit., p. 88. 
عدد خاص بالمؤتمر الدولى السنوى العشرون أ.د/محمد ربيع أنور فتح الباب

\section{المبحث الثاني}

\section{أساس المسؤولية المدنية عن أضرار الروبوتات الذكية}

ذكرت غير مرة، وفي أكثر من موضع سـابق، أن البحث في أسساس المسؤولية

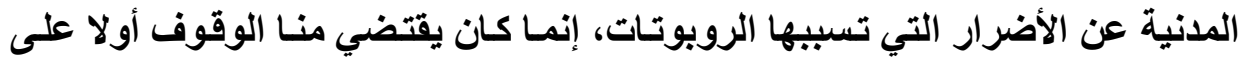

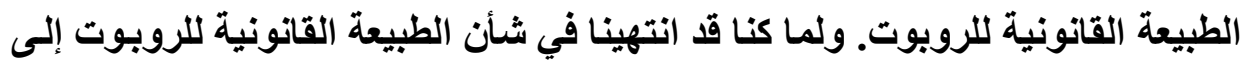

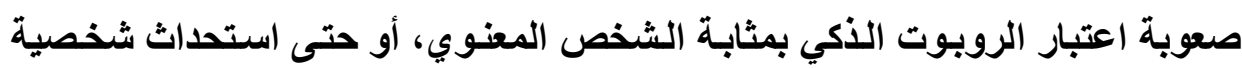
قانونية إلكترونية أو رقمية جديدة لله في الوقت الراهن، على الرغم ممـا انتهي إليه

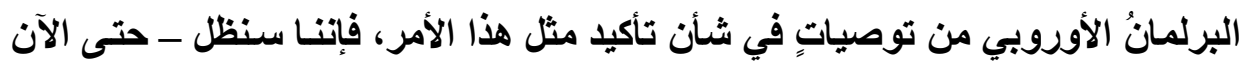
- مستمرين في اعتبار الروبوت الذكي بمثابة الثيء المنقول.

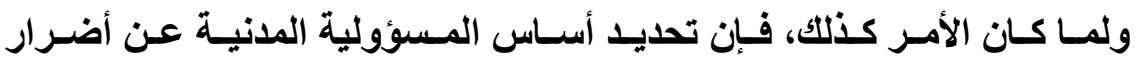
الروبوتـات الذكية لا يخلو من البحث في المسؤولية عن فعل الأثشياء التي تتطلب

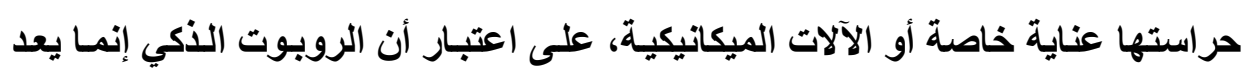

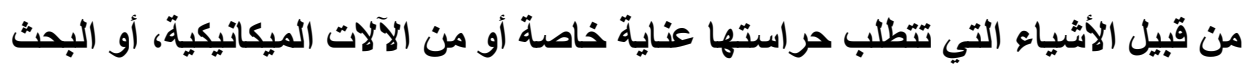

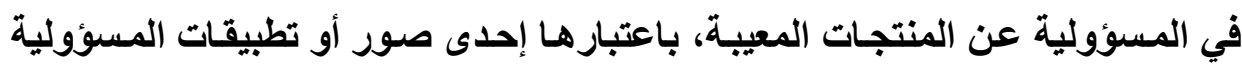

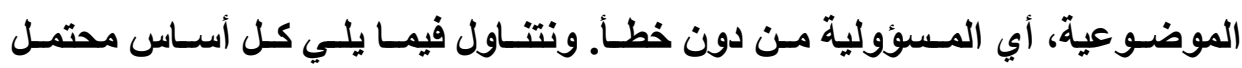

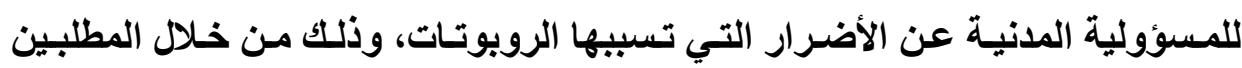
التاليين، على أن ثُبدي الرأي الخاص في المطلب الثالث والأخير. 


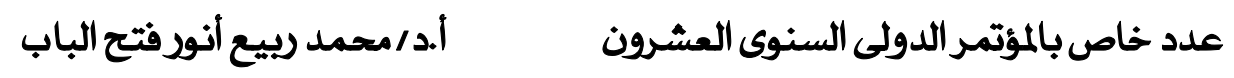

\section{المطاب الأول}

\section{المسؤولية المدنية عن الأشياء كأساس للمسؤولية}

\section{المدنية عن أضرار الروبوتات}

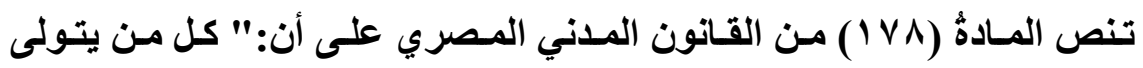

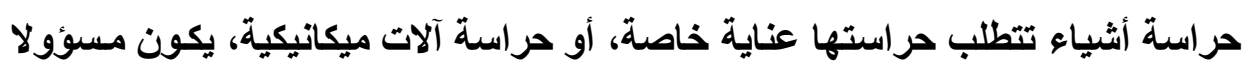

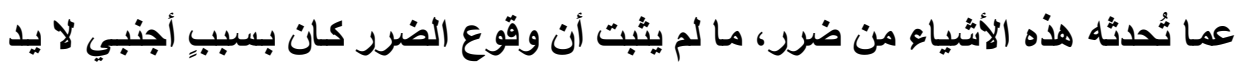

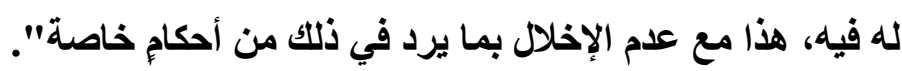
ويتضح من النص القانوني السابق، أنه يُشترط لإقامة مسؤولية حارس الأشياء

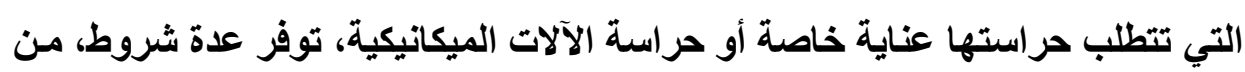

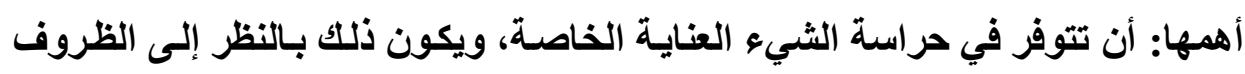

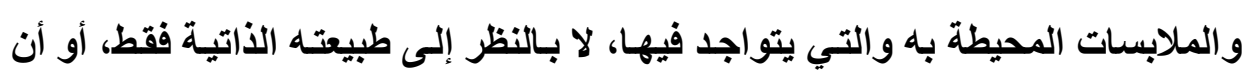

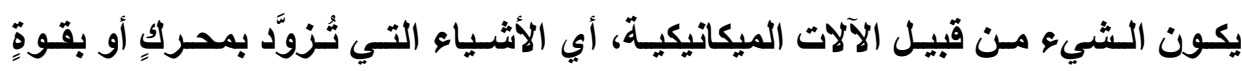

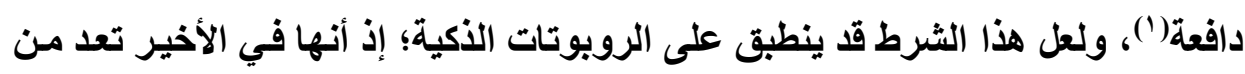

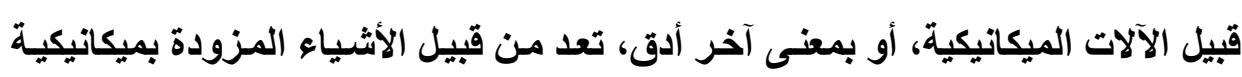

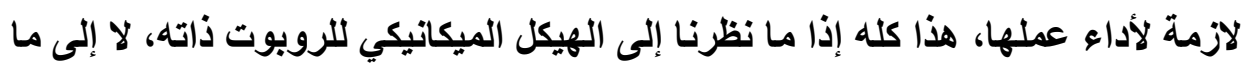

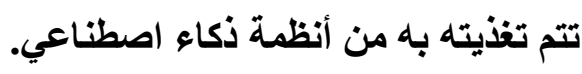

كذلك يشترط أن يكون الروبـوت الذكي في حراسـة الشخص المسؤول عن

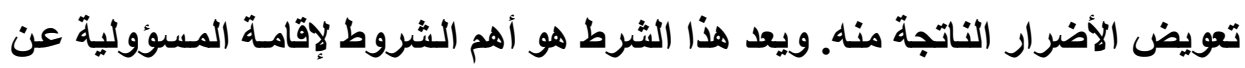

(1) د. محمد ربيع فتح البـاب، د. مها رمضان بطيخ، مسادر الالتزام غير الإراديـة، دار النهضة

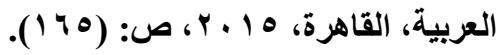




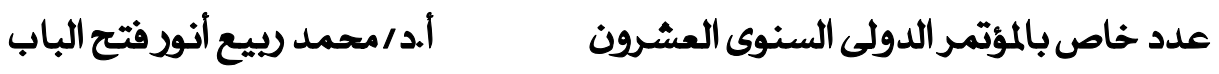

فعل الأشياء؛ ذلك أن الحراسة هي جوهر المسؤولية. والحراسة بهذا الاصطلاح، وعلى وفق ما استقر عليه الرأي في الفقه(') والأحكام القضائية(؟)، يقصد بها الحراسة الفعلية لا القانونية، تلك الحراسة التي تعني السيطرة الفعلية على الروبوت، حتى ولو لـ يكن الحارس هو ذاته المالكك أو المنتفع أو الحائز.

وقد قضت محكمة النقض المصرية في هذا الصدد بـأن:" المقرر - في قضاء

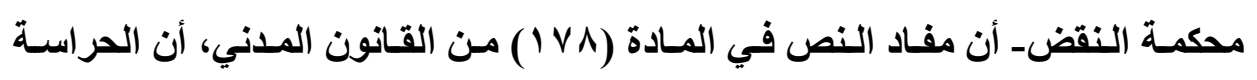
الموجبة للمسؤولية على أساس الخطأ المفترض طبقا لهذا النص، إنما تتحقق بسيطرة الثخص على الثيء سيطرة فعلية في الاستعمال والتوجيه والرقابة لحساب نفسه"(").

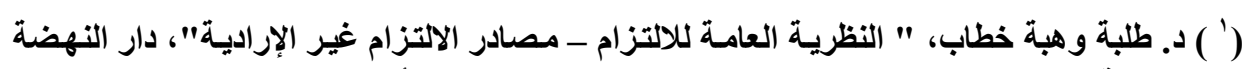

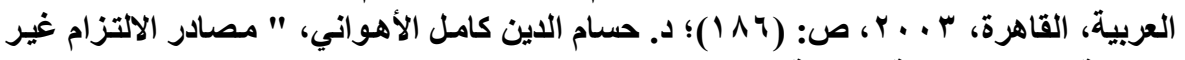

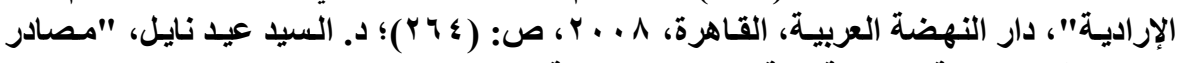

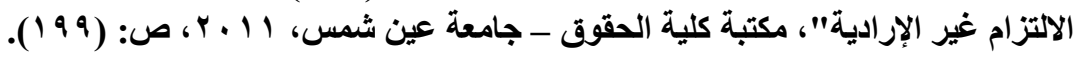

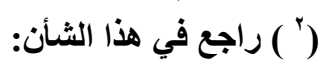

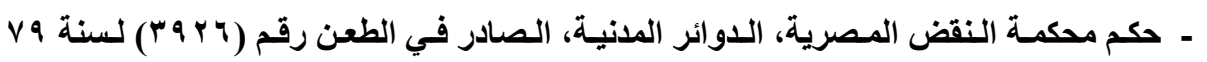

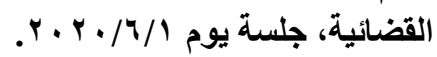

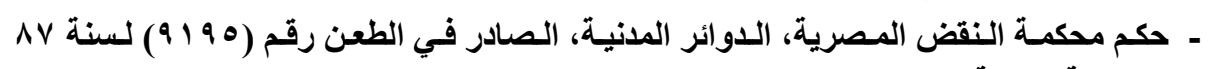

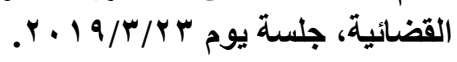

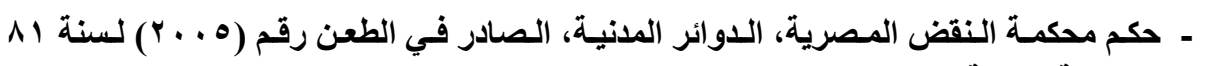

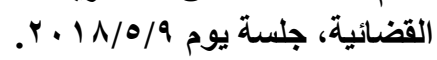

جميع هذه الأحكام القضائية منشورة على الموقع الإكتروني لمحكمة النقض المصرية، عبر الرابط

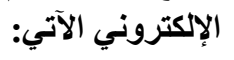
https://www.cc.gov.eg/civil_judgments.

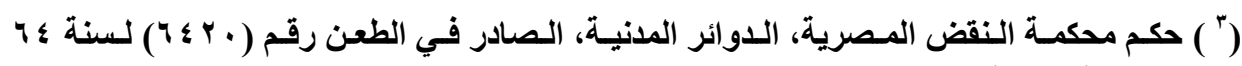

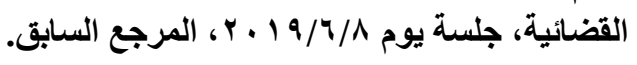




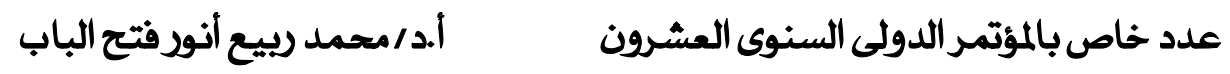

وعند هذا الثرط المتطلب توفره لإقامـة مسؤولية حارس الأشياء التي تتطلب

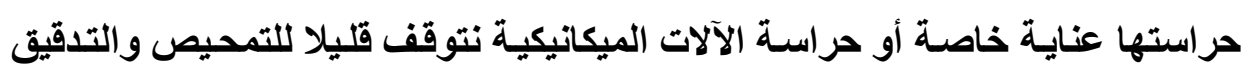
فيه، خاصة عند إنزاله على حالة الروبوتات الأكية، ولنا في ذلك ثلاثةُ أسباب:

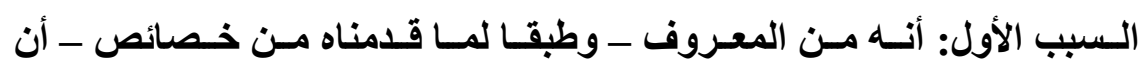

الروبوتات الأكية تتمتع بدرجةٍ عاليةٍ من الذاتية والاستقلالية في العدل، بحيث يصعب

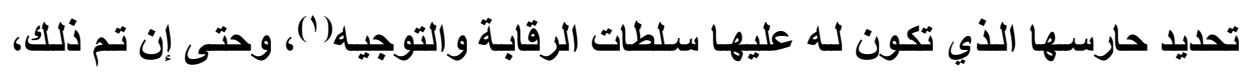
فيكون ذلك لأول مرة فقط، وهي المرة التي يقوم فيها المبرمجُ أو المطورُ أو الشركة أنهات المُصنعة بتغذيـة الروبوت الذكي بنظـام أو برنـامج الذكاء الاصطناعي، بحيث يستطيع

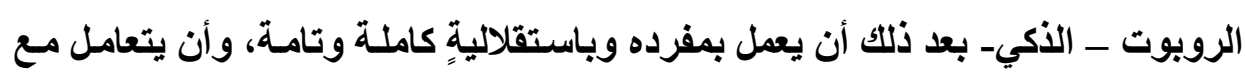

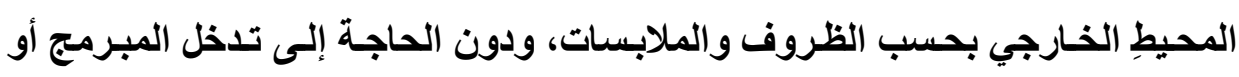
المطور أو الثركة المصنعة.

السبب الثـاني: أن الروبوتـات الأكيـة، وإن كـان مسن الممكن أن تخضع لفكرة

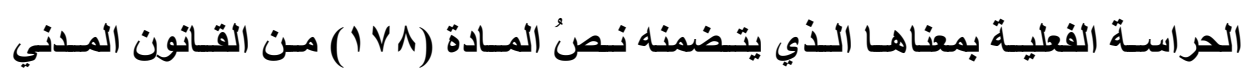

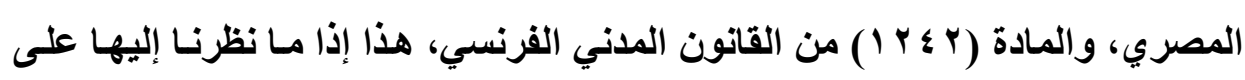

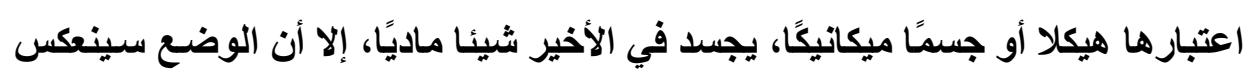
كثيرًا ويتبدل حال نظرنـا إليها على اعتبار هـا نظـام أو برنـامج ذكاء اصطناعي، فعندئـا

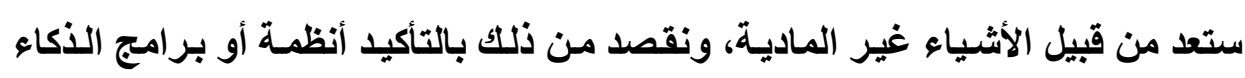
الاصطناعي في حد ذاتها، والتي تعمل من خلالها تلك الروبوتات، لا الروبوت ذاتـه كآلة أو شيء، ومن ثم يصعب إخضاعها - والحالة هذهـ بصورةٍ كلية وتامة لفكرة الحر اسة؛

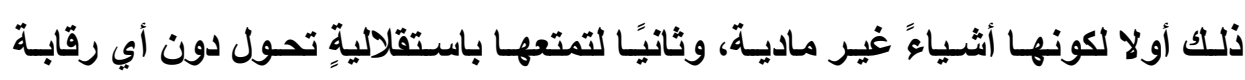

( ${ }^{1}$ Nathalie Nevejans., article précédent. 
عدد خاص بالمؤتمر الدولى السنوى العشرون أ.د /محمد ربيع أنور فتح الباب

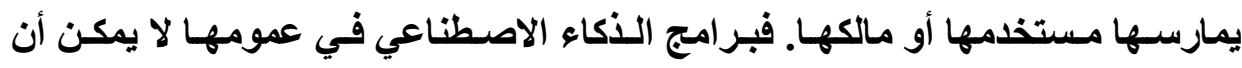

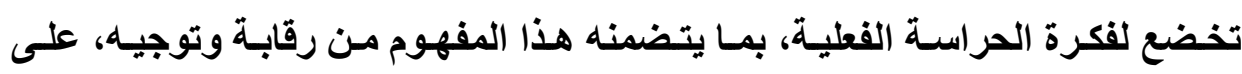

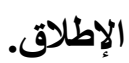

ولعل ما يساندنا في هذا السبب، الحكرُ الصادر عن محكمة الاستئناف بفرنسا في قضية "Google Adwords"، والتي رفضت فيه المحكمة تقرير مسؤولية شركة

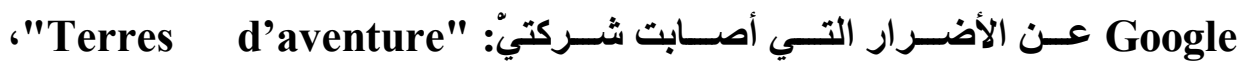

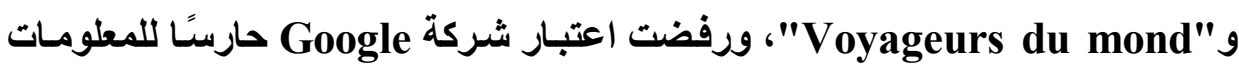

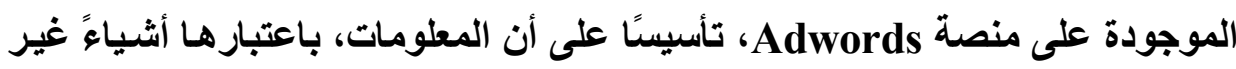

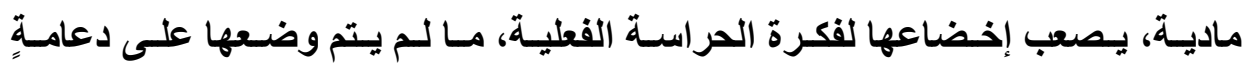

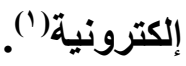

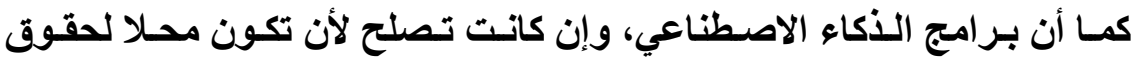
الملكية الفكرية، إلا أنها لا تصلح أن تكون تحت الحراسة الفعلية ـ بمفهومها المتقدم -

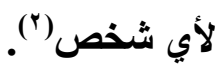

وقد حساول البعضُ من الفقهِهِ الفرنسي(") في سبيل إسناد أسساس المسؤولية

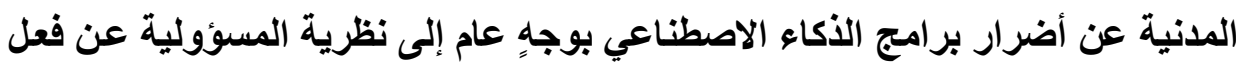

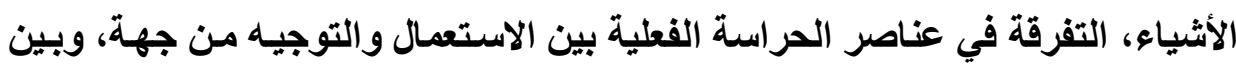

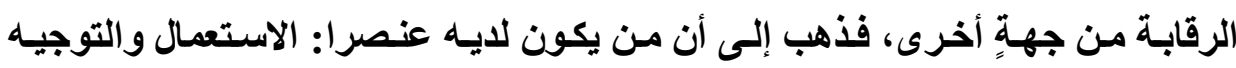

(1) Loiseau (G): “Quelle responsabilité de Google pour le fonctionnement du système Adwords"., CCE., no 6., juin 2014.

(') El Kaakour Nour., op.cit., p. 46.

(3) Nathalie Nevejans: "Traité de droit et d'éthique de la robotique civile., LEH., éd., 2017. P.613. 


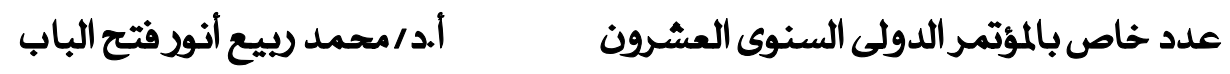

للشيء، يكون هو الحارس الفعلي لله، ودون الحاجة إلى أن يتوفر لـه عنصر الرقابة؛ ذلك أن هذا العنصر الأخير قد يغيب بحسب طبيعة الشيء نفسه.

غير أنتا لا نستطيع تقبل هذا التحليل المتقدم، أو بمعنى آخر أكثر دقة وجرأة، الحيلـة القانونيـة السـابقة؛ ذلك أن الحراسـة الفعليـة تقوم على فكرة السلطة الفعليـة للحارس على الثيء، وهذه السلطة تقتضي أن تتوفر للحسارس ثلاثتة عناصر مجتمعة، هي: الاستعمال والرقابة والتوجيه، ومن دون أي عنصر من هذه العناصر الثلاثة ينهام قوام السلطة الفعلية، وينهام معه بالتبعية قوام الحراسة الفعلية. السبب الثالث: يكمن هذا السبب في صعوبة تحديد الحارس الذي تكون له سلطة فعلية على الروبوت الذكي، فحراسـة برامج الذكاء الاصطناعي في عمومها، تحتوي على أمور فنية معقدة يصعب معها إسناد الثيء الذي تتم تغذيته بها إلى شخصل معين. وحتى وإن أخذنـا بفكرة تجزئـة الحراسـة التي أقرتها محكمـة النقض الفرنسية في حكمها الصادر في ه ينـاير وهـ 9 1، والتي بموجبه جزأت الحراسـة إلى حراسـة

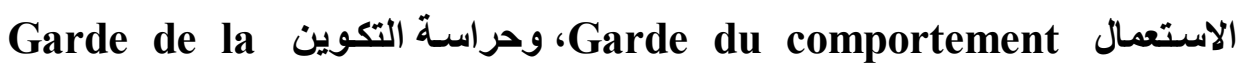
structure واعتبرت بمقتضاها أن حراسـة الاسـتعمال تكون للحسائز في حدود مـا يقتضيه استعمال الثيء، بينما تكون حراسة التكوين للمنتج أو المُصنِّع في نطاق العيب أو الاختلال الموجود في هيكل الثيء، فإن تلك الفكرة قد تثير العديد من الصعوبات أمام المضرور في سبيل إثبات مصدر الضرر، هل هو بسبب عيب تقتي ببرنـامج الذكاء

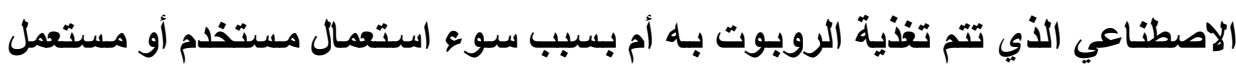
الروبوت؟، ومن ثم تعذر إسناد إحدى الحراستين لأي شخص، ومن ثم صعوبة تحديد

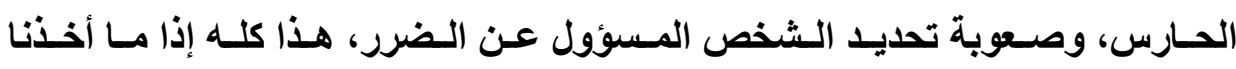
بالحسبان احتمالية عدم إلمسام المضرور بـالأمور التقنية الذكية المستحدثة. ثم مـا هو 
عدد خاص بالمؤتمر الدولى السنوى العشرون أ.د/محمد ربيع أنور فتح الباب

الحل حال كون مصدر الضرر مجهولا، فمن يكون عندئذ الحارس المسؤول عن وقوع

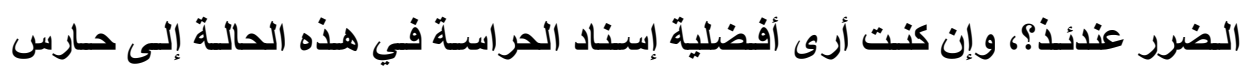

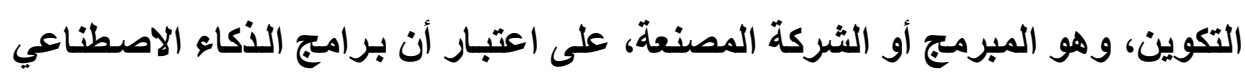
تتمتع بدرجةٍ عالية من التقنية والتعقيد في ذات الوقت.

أمر" آخر أريد أن أسترعي إليه الاتتباه وأدفع بـه في هذا المقام، هو أن مرحلة

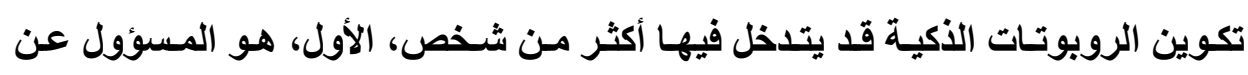

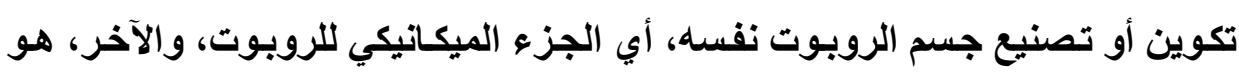

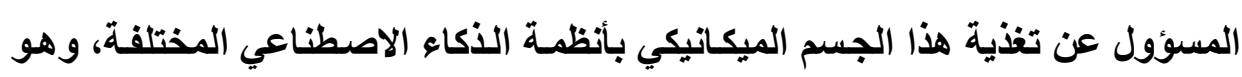

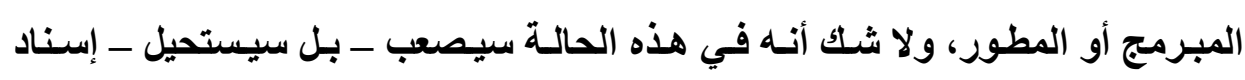

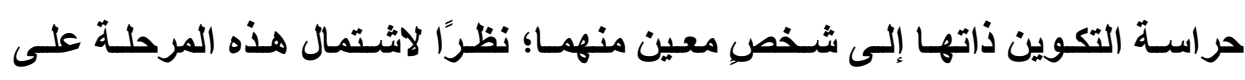
تعقيداتٍٍ تقنية وفنية كبيرة.

لمـا تقدم من أسبابٍ تم الدفع بها من جانبنـا في سبيل محاولية إزاحة نظريـة

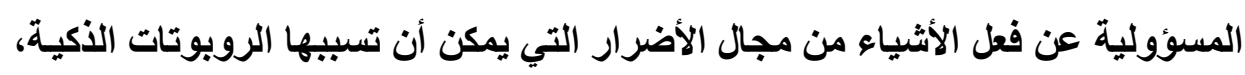

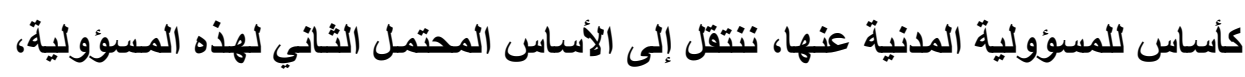
وهو المسؤولية الموضوعية. 


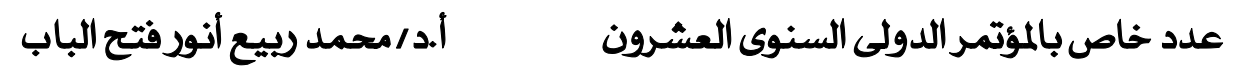

\section{الاملب الثاني}

\section{المسؤولية عن المنتجات المعيبة كأساس للمسؤولية}

\section{المدنية عن أضرار الروبوتات}

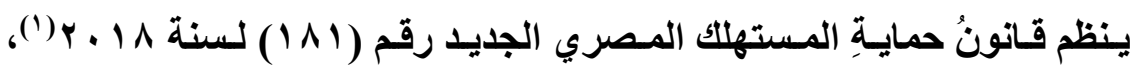

المسؤولية عن الأضرار التي تُحدثها المنتجات، حيث تنص المادة (YV) منه على أن:

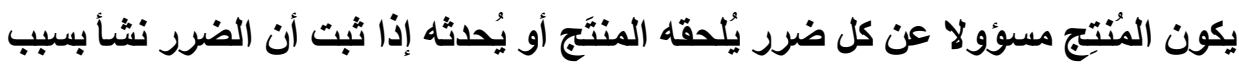
عيب في المنتج يرجع إلى تصميمه أو صنعه أو تركيبه. ويكون المورد مسؤولا عن كل فئل

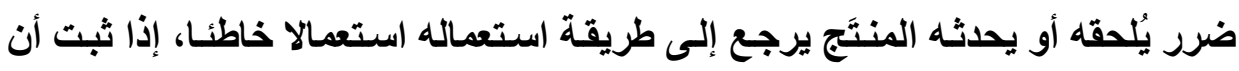

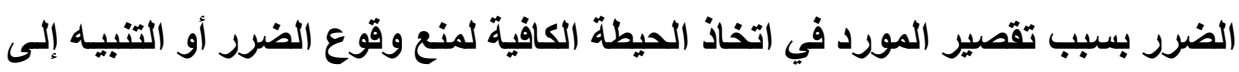

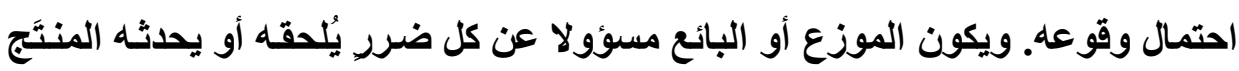

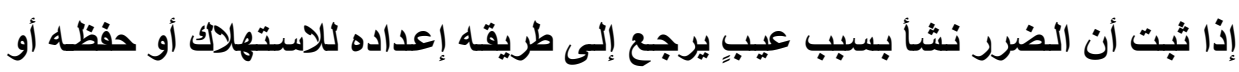
تعبئته أو تداوله أو عرضه. وفي جميع الأحوال تكون مسؤولية الموردين تضامنية".

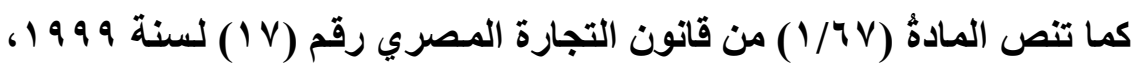

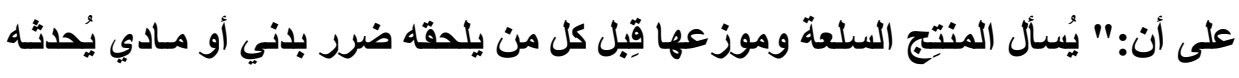

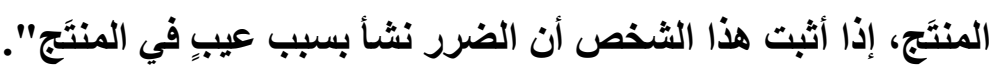
كما يُنظم القانونُ المدني الفرنسي المسؤولية عن المنتجات المعيبة في المواد

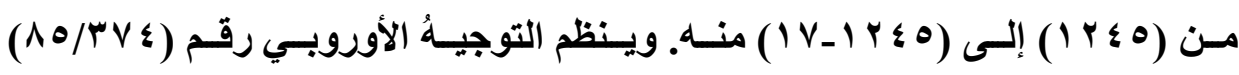

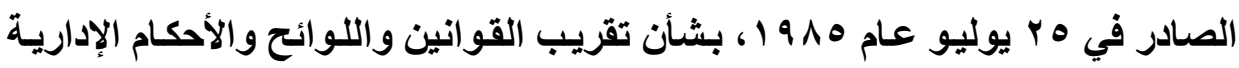

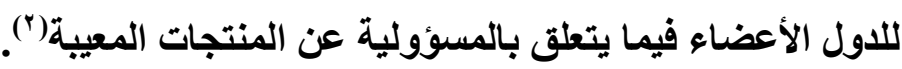

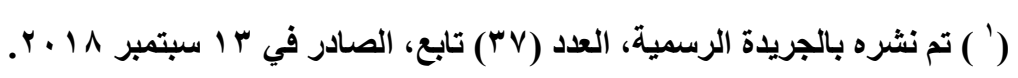

( $\left.{ }^{2}\right)$ https://eur-lex.europa.eu/legal-content/EN/TXT. 


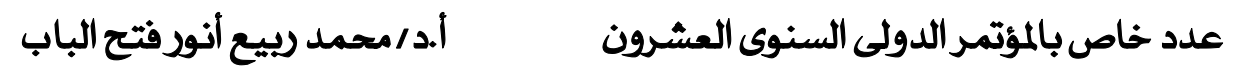

والواقع أن المسؤولية عن الأضرار التي تسببها المنتجـات المعيبة تعد صورة مستحدثة من صور المسؤولية الموضوعية؛ إذ لا يُكلف المضرور من فعل المنتج سوى بإثبات الضرر وعلاقة السبيية بينه وبين العيب، دون أن يُكلف بإثبات خطأ من جانب المنتج، إذ أنه في بعض الأحوال قد يعتري المنتج عيب، دون أن يكون ذلكك راجعًا إلى ثمة خطأ في تصنيعه من قبل المنتج.

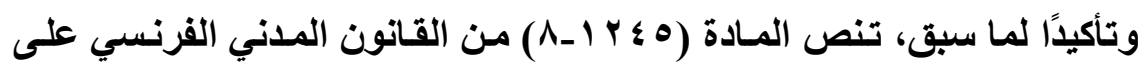
أن:" يجب على المدعي إثبات الضرر والعيب والعلاقة السبية بين العيب والضرر".

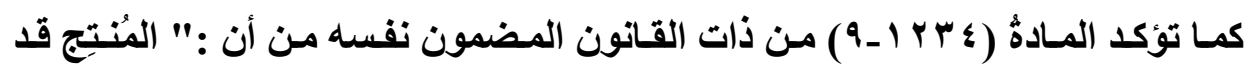
يكون مسؤولا عن العيب على الرغم من أن المنتج قد تم تصنيعه وفقًا للقواعد الفنية أو

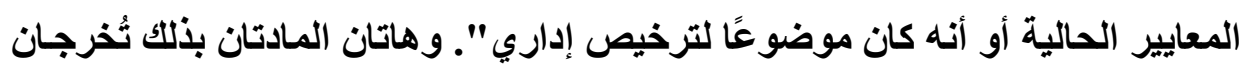
ركنَ الخطأ من نطاق إعمال المسؤولية عن المنتجات المعيبة، وتستبدلانه بركن العيب

والواقع أن المسؤولية الموضوعية هي مسؤولية مستحدثة في القانون المدني، ظهـرت نتيــة وجـود بعض الحـالات التـي يـصب فيهـا على المـضرور إثبـات ركن الخطأ(')، نظرًا لاشتمالها على بعض الأمور الفتية التي يصعب معها على المضرور الإلمام بها. ونُعرَّف المسؤولية الموضوعية بأنها:" المسؤولية التي تتوفر فيها أركانٌ ثلاثة، هي: الفعل أو النشاط، والضرر، وعلاقة السبيية بينهمـا". ويُفهم من ذلك أن المسؤولية الموضوعية تُنحِي ركنَ الخطأ جانبا من نطاقها، وتستبدله بركن الفعل أو وفي

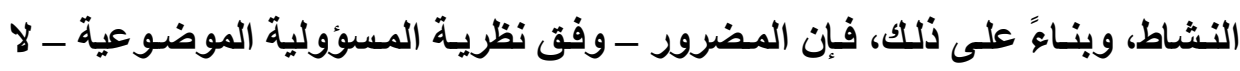




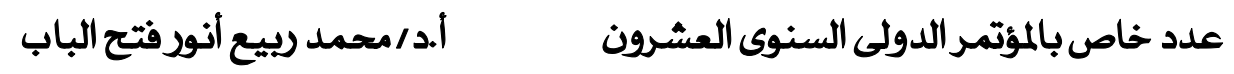

يكُلف سوى بإثبات الضرر وعلاقة السببية بينه وبين الفعل أو النشاط، حتى ولو لم يُشَكل هذا الأخير خطأ، أي حتى ولو لم يتضمن هذا الفعل أو النشاط انحرافا عن السلوك

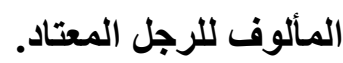

وعودة مرة أخرى إلى البحث في مدى صلاحية نظرية المسؤولية عن المنتجات

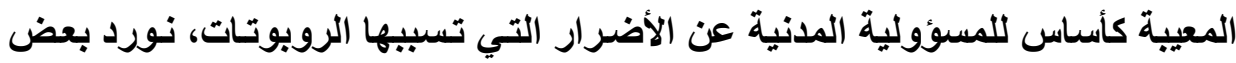
الملاحظات التي سنتتهي من خلالها إلى مدى تناسب تلك النظريـة مـع حالة الروبوتـات الأكية من عدمه:

الملاحظة الأولى تطرح هذه الملاحظة تساؤلا يتعلق بمـدى إمكانيـة إدخـال الروبوتات ضمن اصطلاح "المنتج المنصوص عليه في المادة (YV) من قانون حمايـة المستهلك المصري، والمادة (0 ؛ Y I) من القانون المدني الفرنسي.

وبالذهاب إلى قـانون حمايـة المستهلك المصري الجديد، نجد أن المـادة (1 - ؛) منه، تُعرِّف المنتجات بأنها:" السلع والخدمات المقدمـة مـن أشخاص القـانون العـام أو الخاص، وتثثل السلع المستعملة التي يتم التعاقد عليها من خلال مُورِّد، عدا الخدمات المالية والمصرفية المنظمة بأحكام قانون البنك المركزي والجهاز المصرفي، وقانون تنظيم الرقابة على الأسواق والأدوات المالية غير المصرفية".

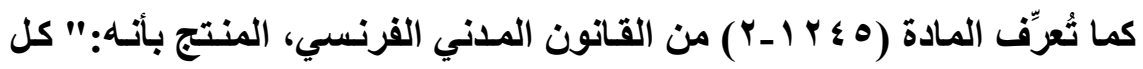
مال منقول، حتى ولو صار جزءًا من عقار، بما في ذلك منتجات الأرض وتربية الماشية والصيد البحري ومنتجات صيد الأسماك. وتعتبر الكهرباء بمثابة منتج"(').

(1) Art (1245-2):" Est un produit tout bien meuble, même s'il est incorporé dans un immeuble, y compris les produits du sol, de l'élevage, de la chasse et de la pêche. L'électricité est considérée comme un produit". 


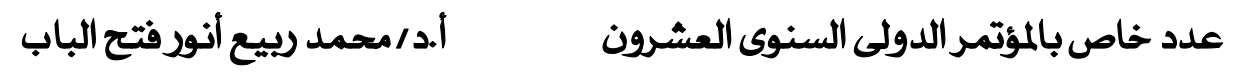

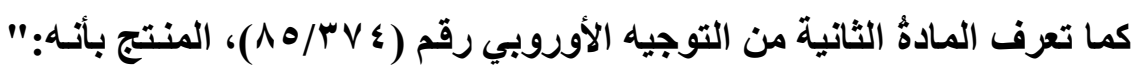
جميع المنقولات، باسنثناء المنتجات الزراعية الأولية والألعاب، حتى وإن كاتت مدمجة في منقولات أخرى أو عقارات" ـ والمنتج يشمل الكهرباء".

ومن النصوص القانونية المتقدمة، يتضح لنـا بجلاء أنها أجمعت على اقتصار اصطلاح "المنتج" على الأشياء المنقولة فقط، وهي الأشياء الماديـة لا تكون مستثرة بحيزهـا أو ثابتة فيـه، ويمكن نقلهـا مـن مكسان إلى آخر دون تلـف، الأمـر الذي يثير التساؤل حول مدى إمكانية إدخال برامج الأكاء الاصطناعي ضمن هذا الاصطلاح.

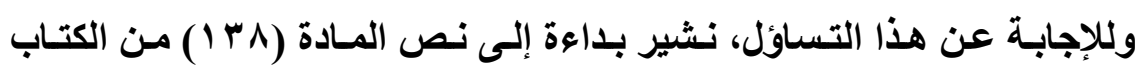
الثالث بعنوان" حقوق المؤلف والحقوق المجاورة"، من قانون حمايـة الملكية الفكريـة

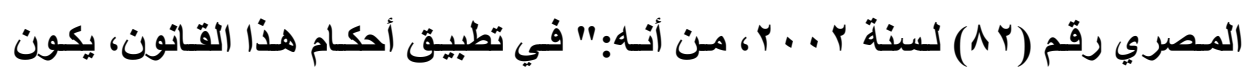

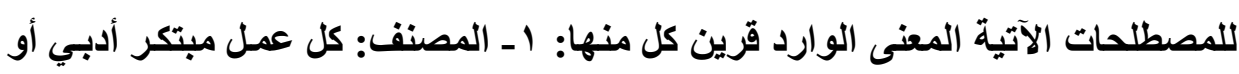
فني أو علمي أيًا كان نوعه أو طريقة التعبير عنه أو أهميته أو الغرض من تصنيفه".

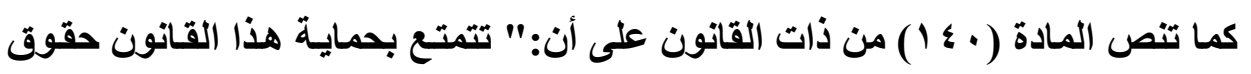

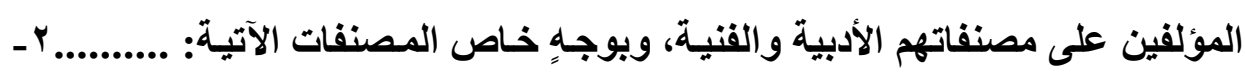
برامج الحاسب الآلي".

أما بالنسبة إلى قانون الملكية الفكرية الفرنسي، فتنص المـادة (1 الج- • 1) منـه على أن:" لا تعبر الاختراعـات التاليـة بـالمعنى المقصود في الفقرة الأولى مـن هذه إهـ

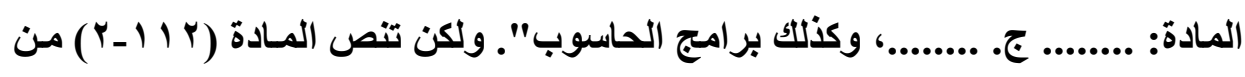
ذات القـانون على أن:" تعتبر على وجـه الخصوص بمثثبـة أعمـالا فكريـة بـالمعنى

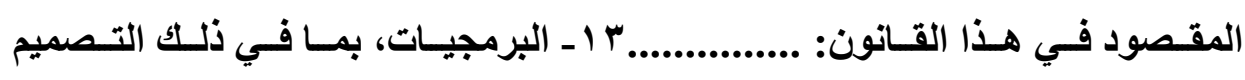
التحضيري". 


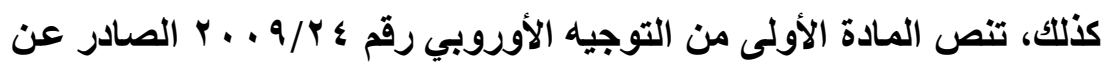

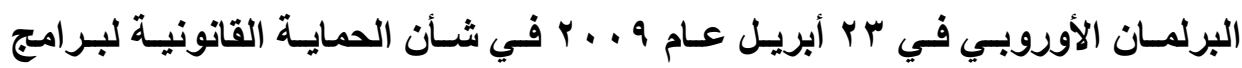
الحاسوب، على أن:" ........... تنطبق الحماية المنصوص عليها في هذا التوجيه على أي شكل من أشكال التعبير عن برامج الكمبيوتر ......".

ويتضح من النصوص المتقدمة، أن برامج الذكاء الاصطناعي تعتبر من قبيل الملكية الفكرية الأدبية والفنية باعتبارها من برامج الحاسب الآلي أو البرمجيـات، ومن

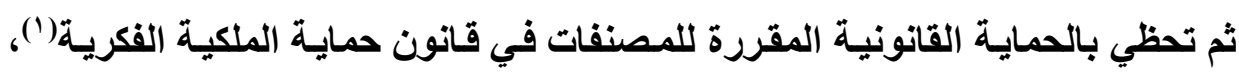
بشرط أن تكون من قبيل المصنفات المبتكرة. ويعرف قـانون حمايـة الملكيـة الفكريـة

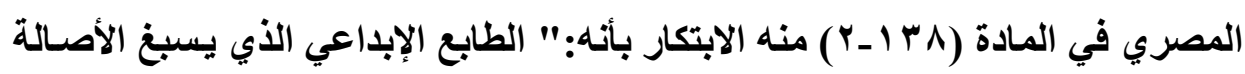
على المصنف"("). هذا من جهة. ومسن جهـةٍة أخـرى، يُشترط لكي يتمتـع أي مـصنف - ومنـهـه بـرامج الـذكاء

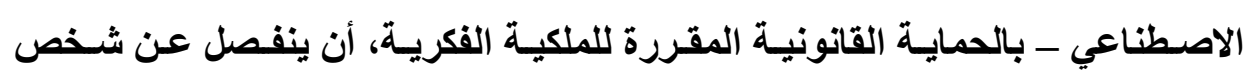
مؤلفه، ويخرج إلى عالم الوجود في شكلٍ محسوس يسمح بتوصيله للغير. ويُعبر الفقه

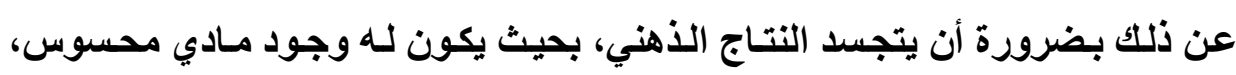

( ${ }^{1}$ Cass.comm. 5 avril 2018, n $^{0}(13-21001)$, www.courdecassation.fr

- Cass.civ., $1^{\text {ère }}, 3$ mai 2018., $n^{0}$ (16-26531), www.courdecassation.fr.

- Cass.civ., $1^{\text {ère }}, 6$ juillet 2017., Arrêt $n^{0} 909$ (16-77.217), www.courdecassation.fr

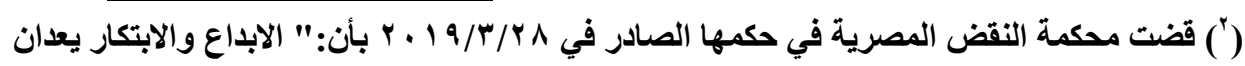

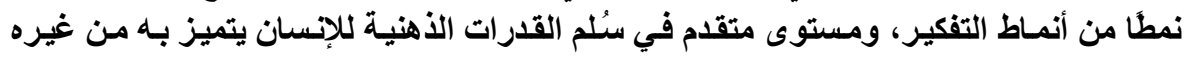

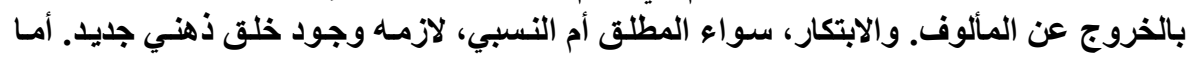

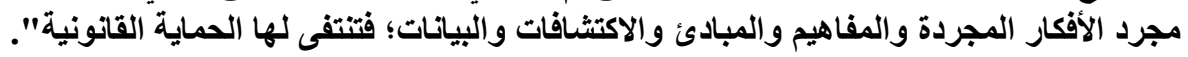

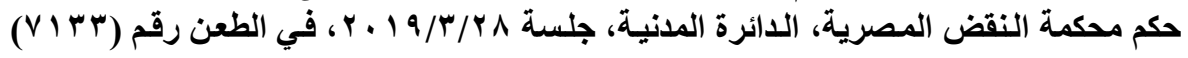

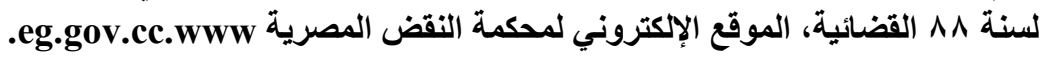


عدد خاص بالمؤتمر الدولى السنوى العشرون أ.د/محمد ربيع أنور فتح الباب

يُمكن للأذهان الأخرى أن ثُركه بأي حاسة من الحواس، كالسمع أو النظر أو اللمس،

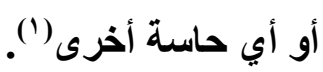

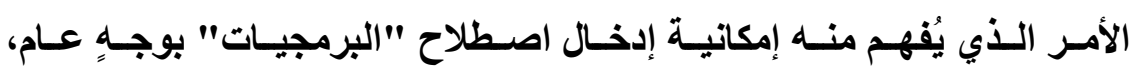

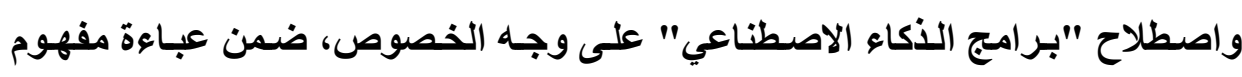

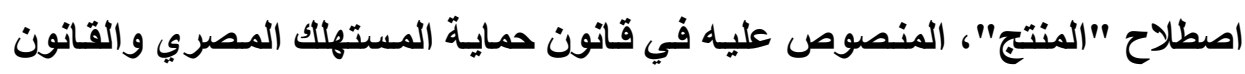

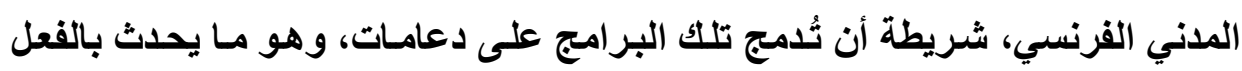
فيما يتعلق ببرامج الذكاء الاصطناعي.

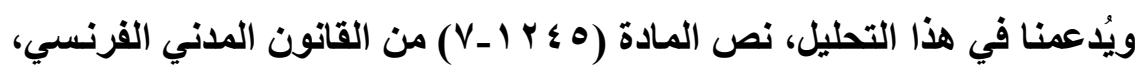

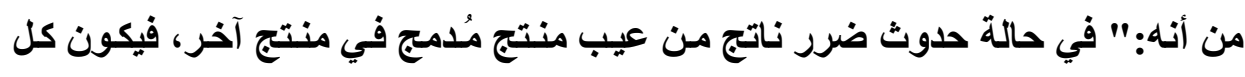

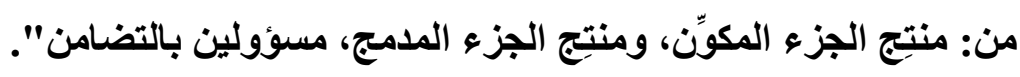

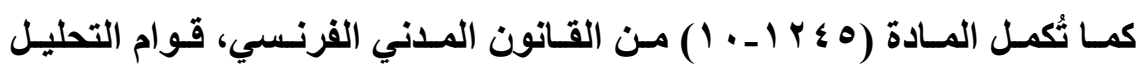

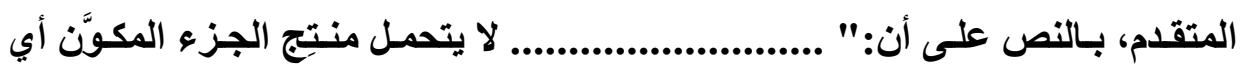

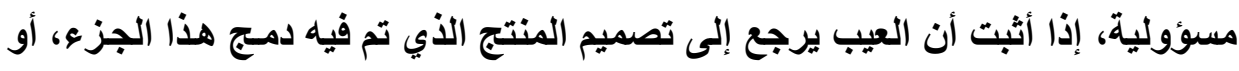

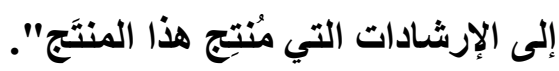

كنلك ندفع في هذا المقام بالتصريح الذي أدلى به كلّ من: وزير العدل الفرنسي،

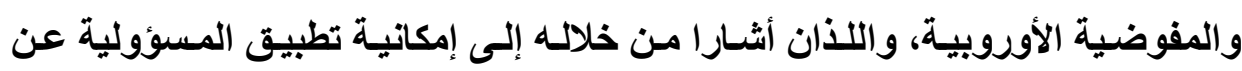

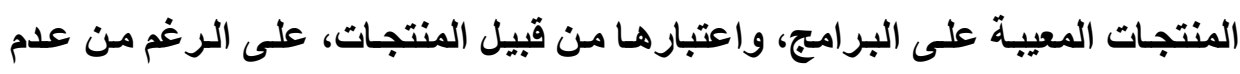
ماديتها.

(') مشار إليه: د. عبد الهادي فوزي العوضي، المدخل لاراسة القانون المصري والعُماني، دار النهضة

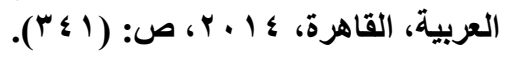


عدد خاص بالمؤتمر الدولى السنوى العشرون أ.د/محمد ربيع أنور فتح الباب

الملاحظـة الثانيـة: تطـرح هـذه الملاحظـة تسـاؤلا يتعلـق بمفهوم "العيبب"

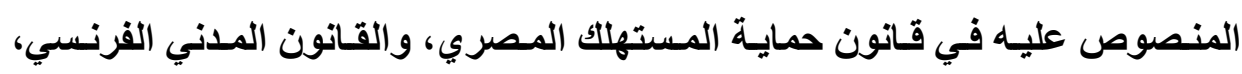

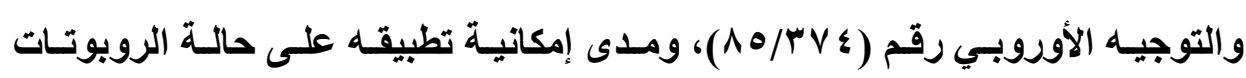
الذكية.

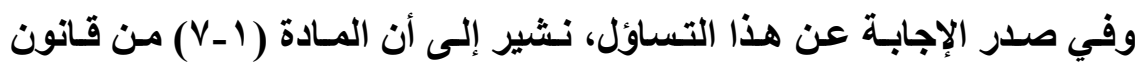

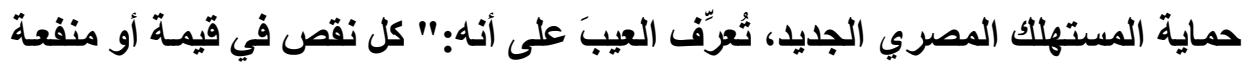

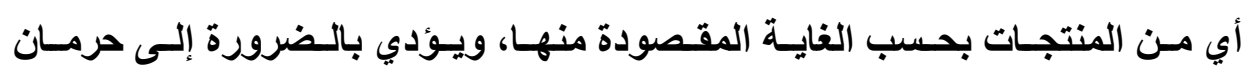

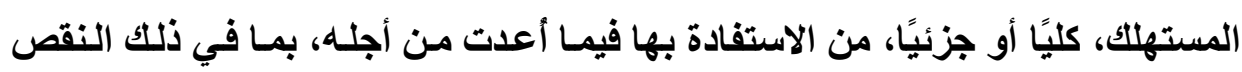

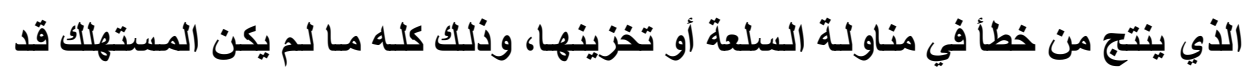

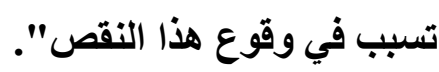

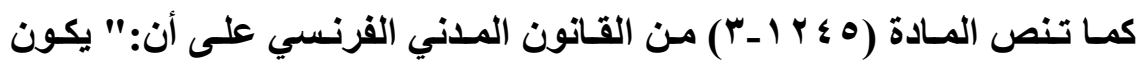

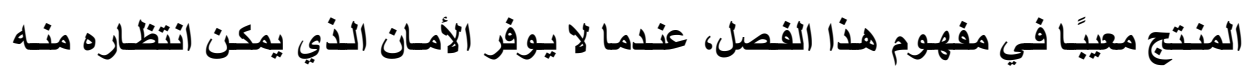
بصورةٍ مشروعة..............

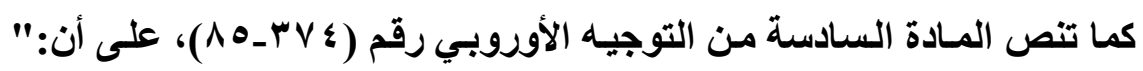

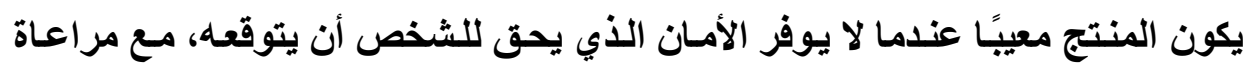

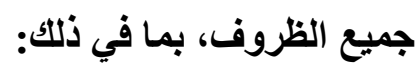
(أ) عرض المنتج.

(ب) الاستخدام الأي من المعقول توقع وضع المنتج فيه. (ج) الوقت الأي تم فيه تداول المنتج.............. 


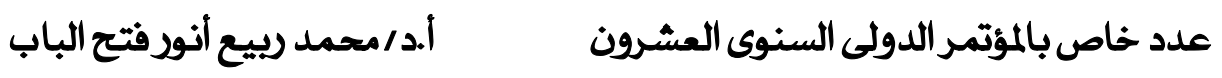

ويتضح من النصوص القانونية الثلاثة المتقدمة، أن العيب المقصود في أحكام

هذه النصوص، هو ذلك العيب الذي لا يـوفر الأمسان الكـافي للمستهللك، ويـؤدي إلى

الانتقاص من منفعة المنتج أو حرمان المستهلك من هذه المنفعة جزئيًا أو كليًا.

وبتطبيق ما تقلم من أحكام على حالة الروبوتات الأكية، نجد أنـه قد يحدث ثمـة

تعارض بينهما؛ ذلك أن برامج الأكاء الاصطناعي - في عمومها -، وإن كانت تعتبر من

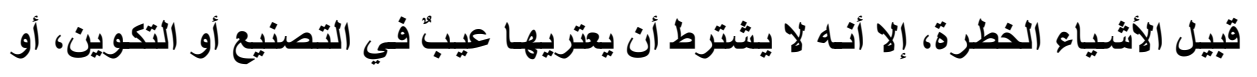
بمعنى آخر، قد تكون رغم ذلك موفرة للأمان الكافي أو المطلوب، ورغم ذلك قد يتسبب تثغيلها في إصابة الغير بأضرار جراء ذلك، خاصـة إذا مـا أخذنا في الاعتبـار الأتيـة والاستقلالية التي تعمل بها هذه البرامج، ممـا قد يجعلها منبتة الصلة في الكثير من الأحيان عن منتجها أو مصنعها، أو حتى مُشظفها.

فإقامـة المسؤولية عن المنتجـات المعيبة في جوهرهـا يستلزم توفر عيب في المنتج، إضافة إلى استلزام قيام المضرور بإثبات هذا العيب، وهو مـا قد لا يتوفر في شأن الرويوتات الأكية لما قدمناه من أسباب. الملاحظة الثالثة: ثُثير هذه الملاحظة تساؤلا فيما يتعلق بتحديد المنتجج المسؤول عن العيب لأجل إقامة المسؤولية المدنية في جانبه. وللإجابة عن هذا التساؤل، نشير إلى أن كلا من: المشرع المصري في المسادة

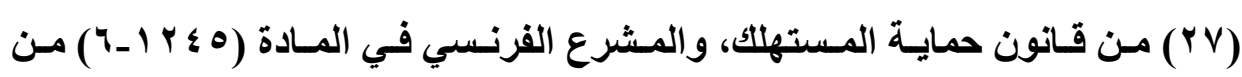

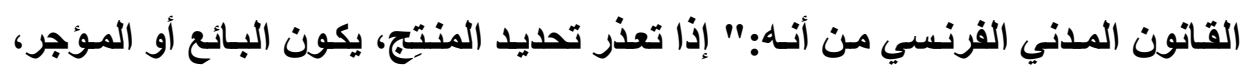

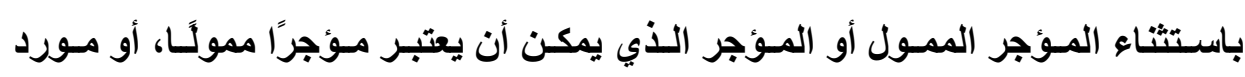
محترف آخر، مسؤولا عن العيب في سـلامة المنتج، في إطسار شروط المنتج ذاتها، إلا 


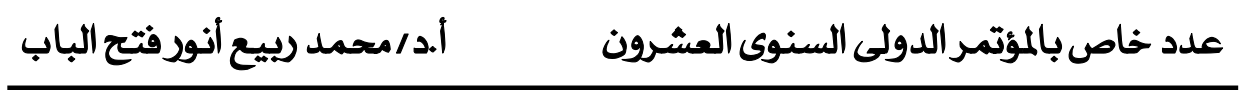

إذا حدده مورده الخاص أو المنتجج، في مهلة ثلاثة شهور، اعتبارًا من التاريخ الذي يُبلغ

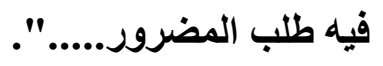

ويُفهم مما سبق، أنه إذا تعذر تحديد شخص المنتِج المسؤول عن العيب، فِان بائع المنتّج أو مؤجره أو المورد المحترف الآخر، بحسب الأحوال، يكونوا مسؤولين عن هذا العيب، غير أنتا قد نصطدم عند إسقاط هذه القاعدة على حالة الروبوتات الذكية باثشكالية صعوبة تحديد منتج الرويوت الذكي؛ إذ قد تتوزع عملية انتاجه بين المصمم والمُصنع والمبرمج، فعملية إنتاج روبوت ذكي تعد - وبحق- عملية تقنية وفنية معقدة للغاية، يصعب من خلالها الوقوف على المنتج النهائي للروبوت الأكي. ونستعيد مما سبق أن أوردنـاه في خضم التحليل الذي جـاء بالملاحظة الأولى،

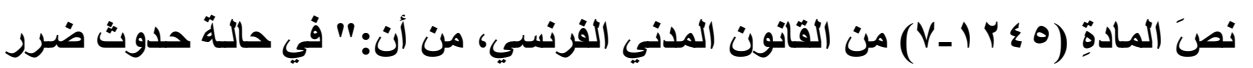
ناتج من عيب منتج مُدمج في منتج آخر، فيكون كل من: منتِج الجزء المكوِّن، ومنتِج منِ

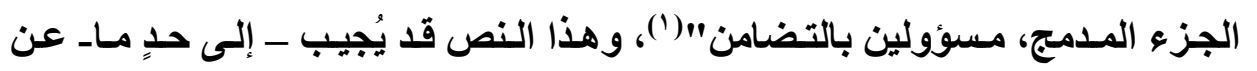
التساؤل المطروح في الملاحظة الحالية، ولكن في حدود الفرض الذي يتم فيـه اللدمج بين جسم الروبوت ذاته وبين برامج الذكاء الاصطناعي التي تتم تغذيته بها، بحيث يكون منتنج الروبـوت ذاتـه والمبرمج أو مطور برامج الذكاء الاصطناعي مسؤولين بالتضامن قِبل المضرور، وإن كان لمنتج الروبوت أن يرجع بعد ذلك على المبرمج أو

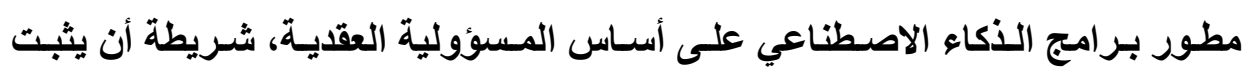
أركانها الثلاثة: الخطأ العقدي، والضرر، وعلاعة الاصنة السببية.

(1) Art (1245-7):" En cas de dommage causé par le défaut d'un produit incorporé dans un autre, le producteur de la partie composante et celui qui a réalisé l'incorporation sont solidairement responsables". 


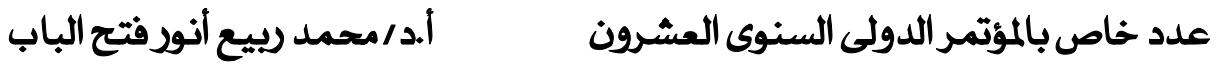

$$
\begin{aligned}
& \text { ونـورد في هذا الصدد مـا يؤكد عدم تناسب نظريـة المسؤولية عن المنتجـات }
\end{aligned}
$$

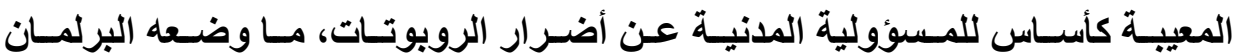

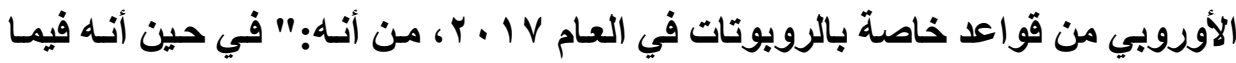

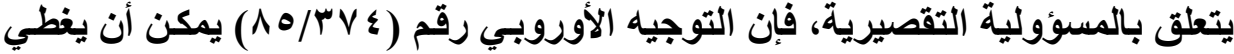

$$
\begin{aligned}
& \text { فقط الضرر الناجم من عيوب التصنيع في الروبوت، بشرط أن يكون الثخص المضرور } \\
& \text { قادرًا على إثبات الضرر الفعلي والعيب في المنتج والعلاقة السببية بين الضرر والعيب، } \\
& \text { وبالتالي قد لا تكون المسؤولية عن المنتجـات المعيبة، أو المسؤولية دون إطار الخطأ } \\
& \text { كافية للتطبيق على حالة الروبوتات الذكية، والتي تكون لها القدرة على التعلم بشكل } \\
& \text { مستقل مـن خبرتهـا المتغيـرة الخاصـة، والتفاعـل مـع بيئتهـا بطريقـةٍة فريــدة وغيـر }
\end{aligned}
$$

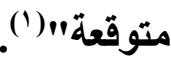

$$
\begin{aligned}
& \text { لمسا تقدم من ملاحظـات تضمنت طرح عدة تساؤلات، تم إيراد إجابـات عنها، } \\
& \text { تشكل في معظمها رفضًا لنظرية المسؤولية عن المنتجـات المعيبة كأسـاس للمسؤولية }
\end{aligned}
$$

(1) Art (AH):" whereas, as regards non-contractual liability, Directive 85/374/EEC can cover only damage caused by a robot's manufacturing defects and on condition that the injured person is able to prove the actual damage, the defect in the product and the causal relationship between damage and defect, therefore strict liability or liability without fault framework may not be sufficient".

Art (AI):" whereas, notwithstanding the scope of Directive 85/374/EEC, the current legal framework would not be sufficient to cover the damage caused by the new generation of robots, insofar as they can be equipped with adaptive and learning abilities entailing a certain degree of unpredictability in their behaviour, since those robots would autonomously learn from their own variable experience and interact with their environment in a unique and unforeseeable manner". 


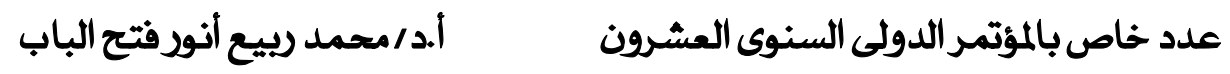

المدنية عن الأضرار التي تسببها الروبوتات الأكية، بجاتب ما تم الدفع بـه في المطلب السابق، من أسباب تفوح بوضوح عن ذات الرفض، نُبين في المطلب التالي الرأي الخـاص في مسألكة الأسـاس القـانوني للمسؤولية المدنية عن الأضرار التـي يمكن أن تسببها الرويوتات الأكية.

\section{الإطلب الثالث}

\section{رأينا الخاص في أساس المسؤولية المدنية عن أضرار الروبوتات}

نـشير بـــاءة، وقبـل إبــاء الـرأي الخـاص فـي مسسألة الأســاس القـانوني

للمسؤولية المدنية عن أضرار الرويوتات الذكية، إلى أن البرلمان الأوروبي في القواعد

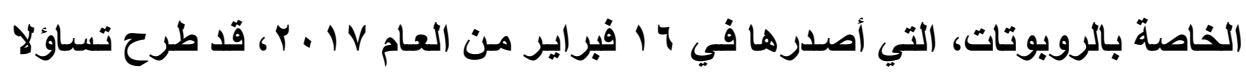
مهما في هذا الصدد، مفاده:" لمـا كاتت الروبوتـات الأكثر استقلالية لا يمكن اعتبارهـا

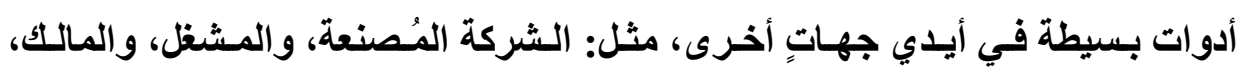

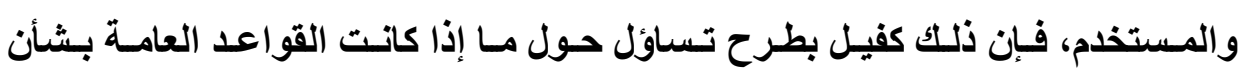
المسؤولية المدنية كافية بذاتها لإقامة المسؤولية عن أضرار الروبوتات على أساسها؟؛ أم أن هنـاك حاجـة تـدعو إلى إقرار قواعد جديدة لتوفير الوضـوح بشأن المسؤولية المدنيـة لمختلف الجهات الفاعلـة فيمـا يتعلق بالمسؤولية عن أفعال الرويوتـات؛ إذ لا يمكن نسبة الضرر إلى فاعل بشري معين؟. كما أنه لا يمكن اعتبار الرويوتات مسؤولة

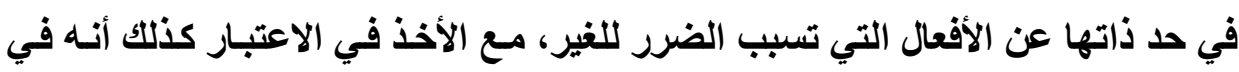
الحالة التي يمكن فيها للروبوت اتخاذ قرارات مستقلة، لن تكفي القواعد التقليدية لإثارة المسؤولية المدنية عن الضرر الذي يسببه الروبوت؛ لأنها لن تجعل من الممكن تحديد الطرف المسؤول عن تقديم التعويض ومطالبته بأدائه إلى المضرور". 


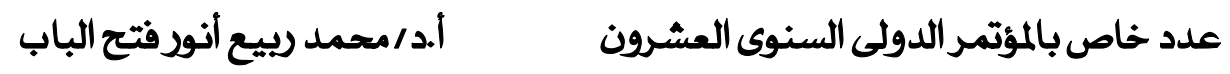

وتأكيدًا لما أوصى به البرلمان الأوروبي في هذا الصدد، من ضرورة النظر في

مسألة إقرار نظـام قـانوني جديد للمسؤولية المدنيـة عن أنظمـة الذكاء الاصطناعي،

ومنها الروبوتات، ذهب بعض الفقهاء، وحتى قبل إصدار هذه التوصيات، إلى تشجيع إنشاء نظام قانوني خاص بالروبوتـات، حيث يؤكد الفقيه Alain Bensoussan في

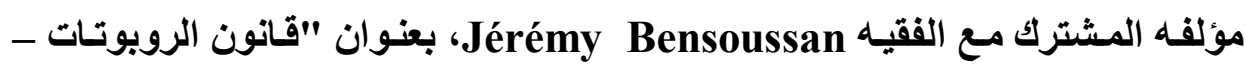
مؤDroit des robots مدنية جديد خاص بالروبوتات الأكية، بحيث يمكن أن تقوم معه المسؤولية التقصيرية عن الأفعال الشخصية للرويوتـات، هذا كله بعد الاعتراف للروبوت بشخصية قانونية رقمية، تختلف في طبيعتها عن الشخصية القانونية الممنوحة للشخص الطبيعي، وكذلك الشخصية الاعتبارية.

غير أن بعض الفقهاء الفرنسيين اتخذ موقفا وسطا بين المسؤولية الموضوعية

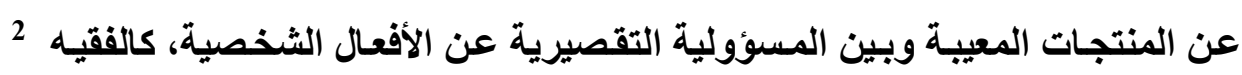
Maitre Alain ، الذي اقترح إنشاء مسؤولية مدنية متتابعة أو هرمية، بحيث يتم تحديد الثخص المسؤول عن الضرر وفق مدى مساهمته في عملية تشغيل الروبوت، مع الاعتماد على سبب الضرر، وبحيث يتم تحميل المسؤولية أولا عن الأضرار التي ملي يسببها الروبوت لمستخدمه؛ إذ أنـه هو الذي يتفاعل مـع الروبوت الخـاص بـه، ولايـه

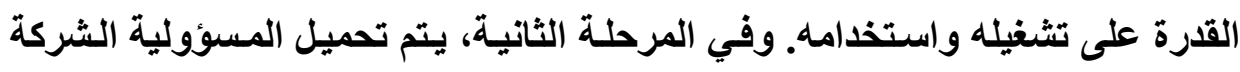
المصنعة أو المنتجة للجسم الميكانيكي للرويوت ذاته، وذلك حسال ثبوت أن الضرر كان بسبب فعل المكونات المادية لهذا الجسم، على أن يتم إعفـاء الشركة المُصنعة للجسم

(1) Bensoussan (A.) et Bensoussan (J):” Droit des robots, Éd Lrcier., 2015., p.51.

(2) Cité par: El Kaakour Nour., op.cit., p.86. 
الميكانيكي للروبـوت مـن المسؤولية، إذا ثبت أن حدوث العيب كـان بسبب التقنيـة المستقلة الخاصة بنظام الذكاء الاصطناعي ذاته، والذي يتم تغذية الرويوت بهان. وفي رأينا، ونظرًا لعدم تتاسب ما تم الافع به من نظريات في المسؤولية المدنية

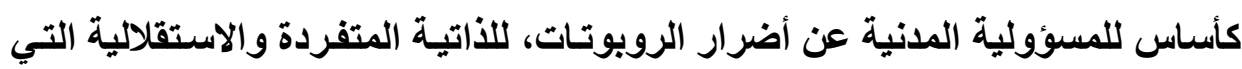

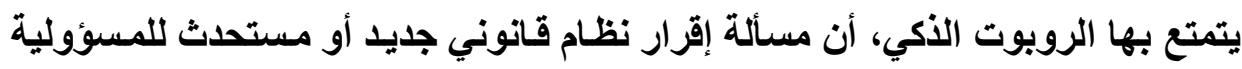
المدنية عن أضرار الرويوتات، بما يجطها مسؤولة مسؤولية شخصية عن أفعالها، إنما يتطلب بداعة الاعتراف لها بشخصيةٍ قانونية مستقلة، على غرار الثخصية القانونية

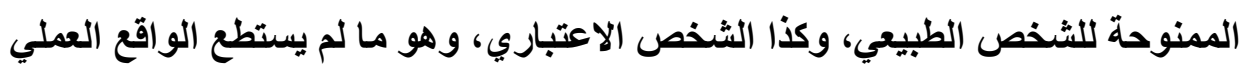

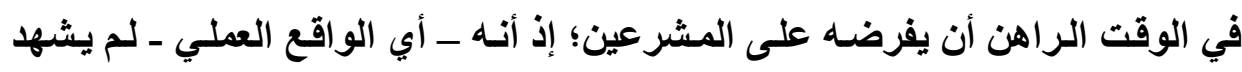

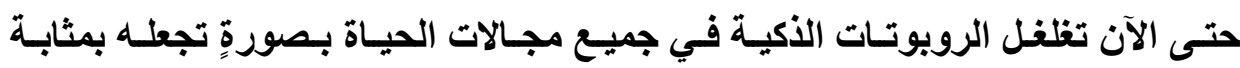
الظاهرة التي تحتاج إلى تنظيم تثريعي خاص بها، ذلك أن الظاهرة تبدأ أولا وتنتشر،

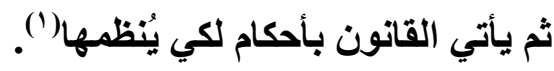

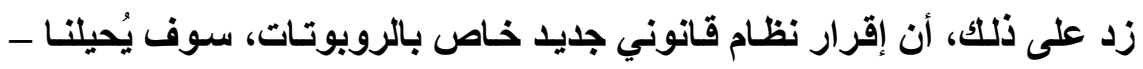
بالتأكيد - إلى مسألة وفاء المدين بالتعويض المستحق أو المحكوم به، ولا يتصور عقلا

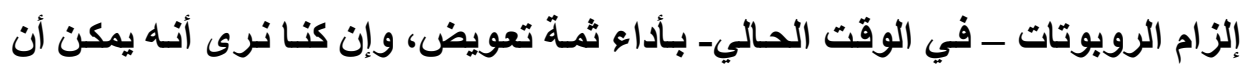

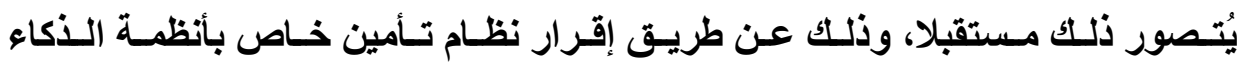

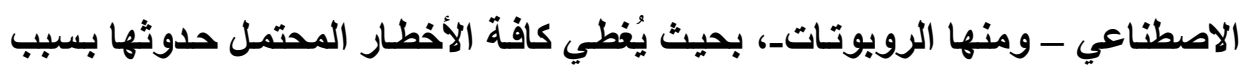

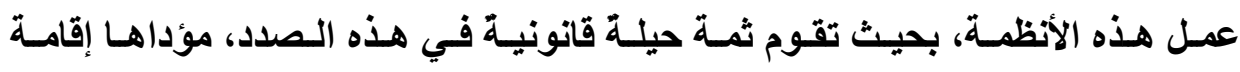

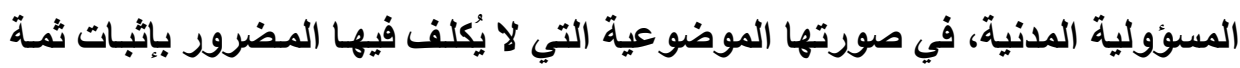
(') د. نبيل إبراهيم سعد، المدذل إلى القـانون (نظريـة الحق)، دار الجامعة الجديدة، الاسكندرية، (11) (1) (1) 


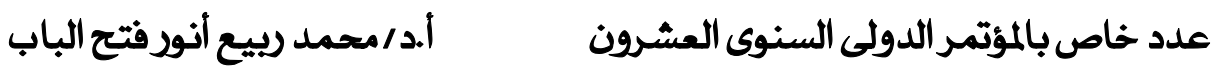

خطأ، في جاتب الروبوت عن أفعاله الثخصية، مع اقتضاء التعويض من مبلِغ التأمين الأي يلتزم بسداده، وبالتضامن، كل من تـخل في عمليـة تكوينه، من: شركة مُصنعة

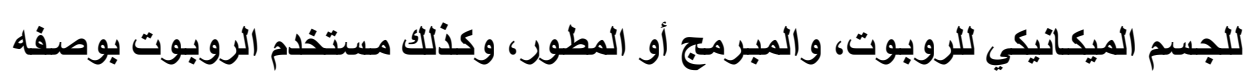
مسؤولا عن عملية استعماله.

ولعل هذا هو مـا أوصسى بـه البرلمسانُ الأوروبي من إنشـاء نظـام تـأمين خـاص

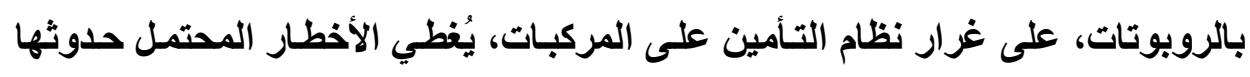

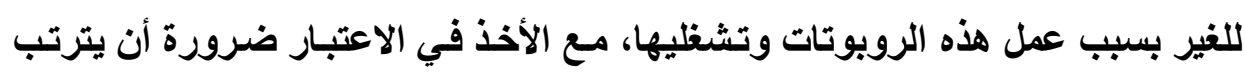
على حدوث تلك الأخطار أضرار، مادية أو أدبية، تصبي الغير. خلاصـة القول إذن، أن أسساس المسؤولية المدنية عن الأضرار التي يمكن أن تسبيها الروبوتـات يختلف عمـا سبق طرحه وتحليله من نظريـات خاصسة بالمسؤولية

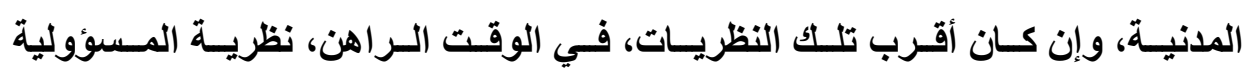
الموضوعية عن المنتجات المعيبة، ولكن مع بعض الاختلافـات التي تتفق مع طبيعة أنظمة برامج الذكاء الاصطناعي، والتي يمكن أن نوضحها على النحو الآتي: - عدم اشـتراط إثبـات المضرور لعيب في الروبـوت، واستبدال هذا الـركن بـركن الحادث أو النشاط ذاته، دون تطلب أن يقترن هذا الحـادث أو النشاط بثمـة خطأ، وما في ذلك سوى العودة مرة أخرى إلى القوام الرئيس والتاريخي الذي تقوم عليه نظرية المسؤولية الموضوعية.

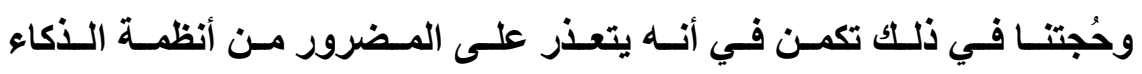
الاصطناعي، بما تتضمنه من أمور تقتية معقدة، إثبات وجود ثمة عيب فيها من عدمـه؛

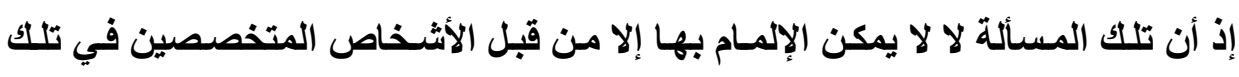




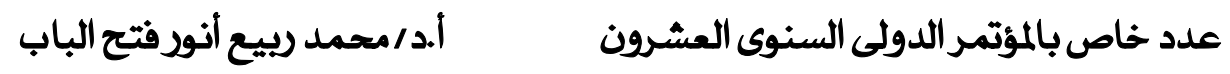

- - إقرار نظام تأمين إلزامي يُغطي كافة الأخطار التي قد تقع مستقبلا بسبب عمل

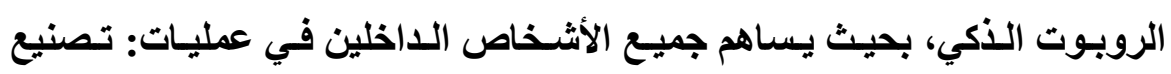
الروبوت، وبرمجته، وكذلك استخدامه، في هذا النظام، على أن يستحق المضرور، متى أثبت وجود أركان المسؤولية الموضوعية، من: حسادث أو نشاط، وضرر، وعلاقة سبيية بينهما، التعويض من هذا النظام أو الصندوق، وذلك لأجل معالجة مشكلة شيوع المسؤولية بين الأشخاص المساهمين في إخراج الروبوت الذكي، وتعذر تحديد المسؤول عن الضرر بينهم من قبل المضرور.

وأخيرًا، يجب أن يتأهب مشرعو الدول لما سيكشف عنـه المستقبلُ القريب من إحلال الروبوتـات الأكيـة محل البشر، والقيـام بـات الأعمـال التـي يقوم بهـا الإنسان البشري، بل بكفاعةٍ ودقة وسرعة تفوق البثر، ومن ثم النظر في مسألة مدى إمكانيـة

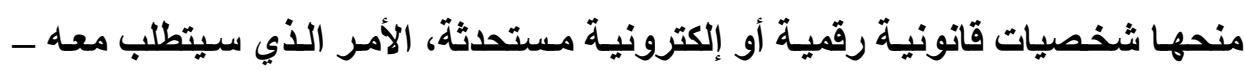
وبالتبعيةـ النظر في مسألة إقرار نظام قانوني خاص بالمسؤولية المدنية عن الأضرار التي يمكن أن تسببها الروبوتات الذكية للغير، ذلتك النظام الذي يجب بالتأكيد أن يقوم على أساس من المسؤولية الموضوعية المجردة من ركن الخطأ أو حتى ركن العيب. 


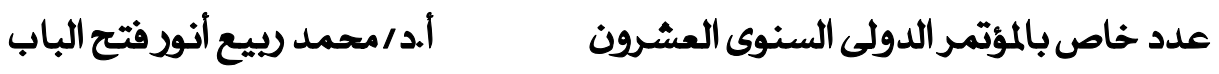

الخاتمة

بعد أن انتهينا من خوض غمار موضوع "الطبيعة القانونية للمسؤولية المدنية عن أضرار الروبوتات"، والتعق فيه، وتحليل عناصره، نسنطيع أن نخرج منه ببعض النتائج المهمة، ونوصي ببعض الأمور التي نراها يُمكن أن تسد فراغًا تثريعيًا.

أولا: النتائج

- - تعد الروبوتات الذكية أحد أهم تطبيقات الذكاء الاصطناعي، والذي كاتت ولادته الحقيقية في العام ه 97 ا ـ وقد تم استخدام اصطلاح "روبوت"، لأول مرة من قبل الكاتب المسرحي "Karel Chapek" في العـام • ب و 1 ، كمـا تمت صناعة أول

روبوت في التاريخ في اليابان، في العام ^ ^ 9 1، تعت اسم Gakutensoku.

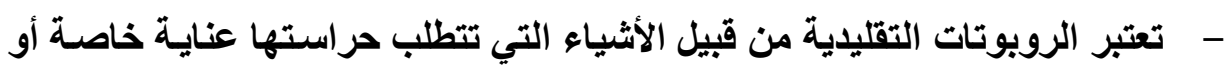
من قبيل الآلات الميكانيكية، بالمعنى الاقيق لاصطلاح الأشياء المنصوص عليه في

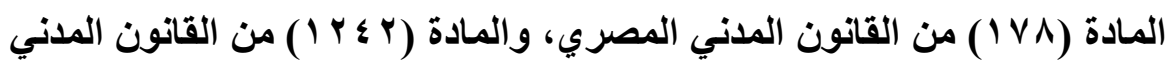
الفرنسي؛ ذلك أن هذا النوع من الرويوتات يفتقر لنظام الأكاء الاصطناعي، بحيث

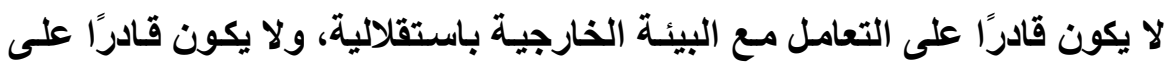
اتخاذ القرارات المناسبة من تلقاء نفسه، ومن ثم تخضع الروبوتات التقليدية، من

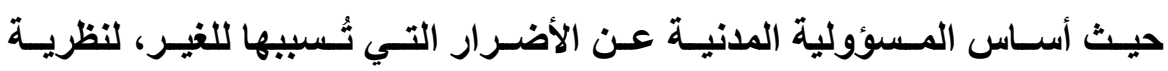
المسؤولية عن فعل الأشياء المنصوص عليها في هـاتين المـادتين، متى توفرت شروط قيام هذه المسؤولية، ومن أهمها الحراسـة الفعلية، أو لنظريـة المسؤولية

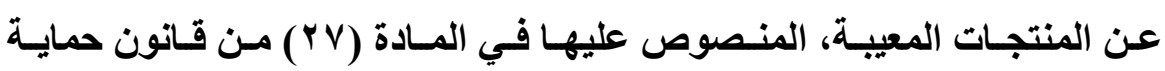

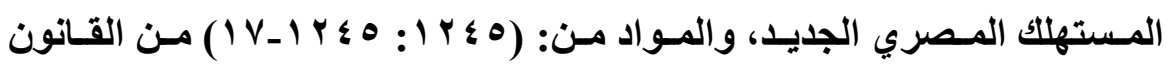

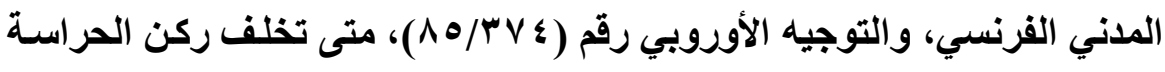


عدد خاص بالمؤتمر الدولى السنوى العشرون أ.د/محمد ربيع أنور فتح الباب

الفعلية، وتوفرت شروط إعمال تلك المسؤولية، وخاصة فيما يتعلق بوجود عيب

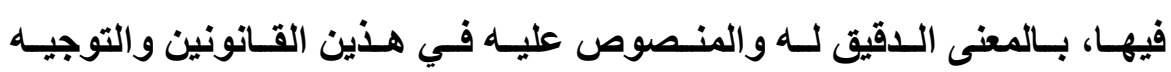
الأوروبي. - أما بالنسبة إلى الروبوتات الأكية، وهي تلك الروبوتات التي تتمتع باستقلالية في

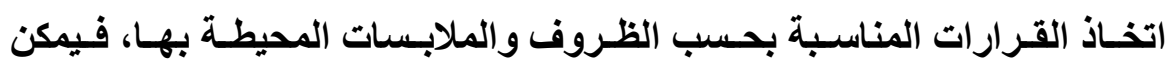

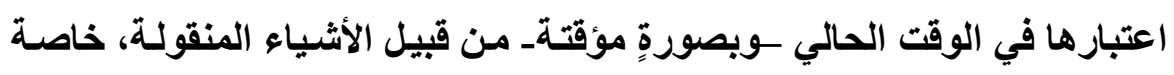

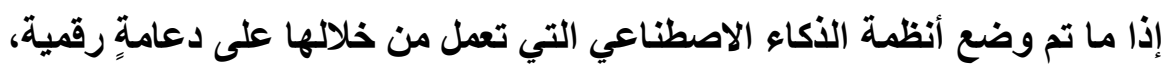

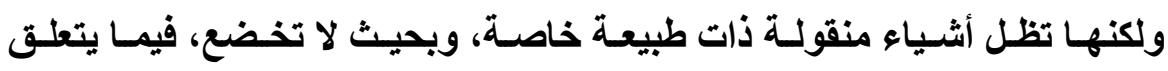

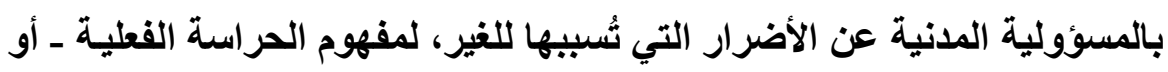

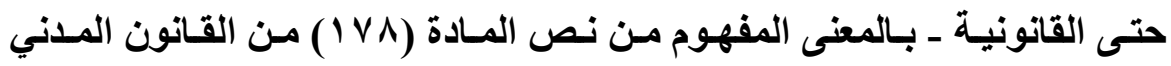

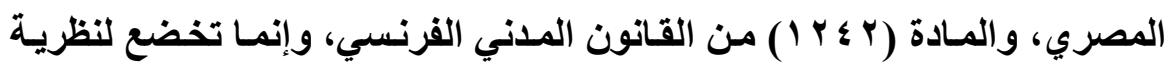

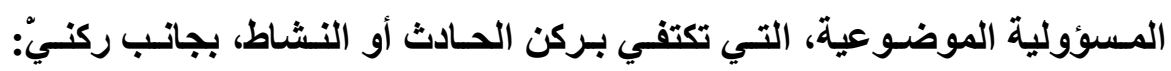
الضرر، وعلاقة السببية، ودون الشتراط أن يثكل هذا الحادث أو النثاط ثمة خطأ.

\section{ثانياً: التوصيات}

من منطلق حرصنا على عدم الاكتفاء بما وصلت إليه برامج الذكاء الاصطناعي

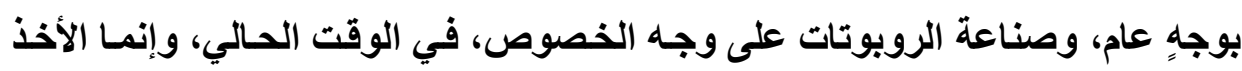

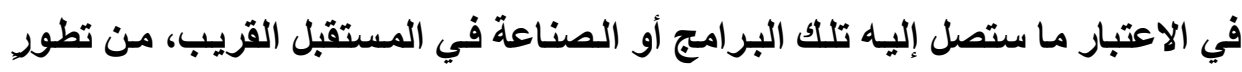

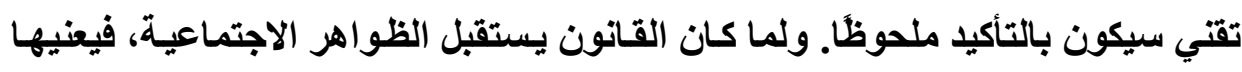
بالتنظيم، أوصي المشرع المصري، في هذا الصدد، بالآتي: - - النظر في مسألة الاعتراف التشريعي بما يتم إجراؤه من معاملات تتم باستخذام

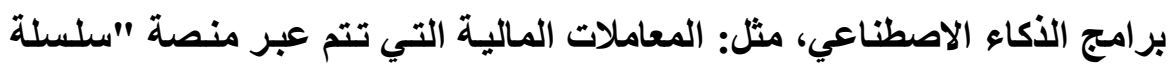




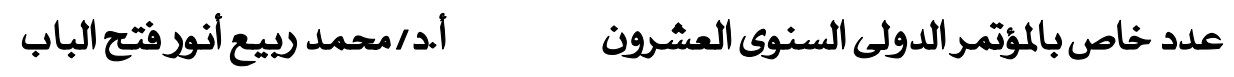

الكتل - Blockchain"، وكـلكك العقود ـ الأكيـة ـ التـي ثُبـرم عبرهـا، وأيضا المعاملات التي تتم باستخدام العملات الرقمية، مع النص على ضوابط معينة تكفل حسن تحقيق أغراضها المشروعة. - النظر في مسألة منح حقوق براءات الاختراع عن برامج الأكاء الاصطناعي، متى تـوفرت الشروط المتطلبـة لـنلك، والمنصوص عليهـا في قانون حمايـة الملكيـة الفكرية. - - النظر في مـدى إمكانيـة استتيعاب "نظريـة الشخص الاعتبـاري " لأنظمـة الـكاء الاصطناعي، والبحث في مدى الحاجة إلى إنشاء شخصيةٍ قانونيةٍ جديدة تثناسب مع الطبيعة الذاتية والمتفردة لتلك الأنظمة. - النظر في مسـألة إقرار المسؤولية الموضوعية في مجـال الأضـرار الإكترونيـة والتقنية بصورةٍ عامة، بحيث يتم استبعاد ركن الخطأ من مجال قيامها وإعمالها؛ نظرًا لصعوبة - وربمـا استحالة ـ نجـاح المضرور في إثبات ثمـة أخطاء فيها، لاحتوائها على أمور فنية وتقتية معقدة. 
عدد خاص بالمؤتمر الدولى السنوى العشرون أ.د/محمد ربيع أنور فتح الباب

\section{قائمة المصادر والمراجع}

أولا: المصادر

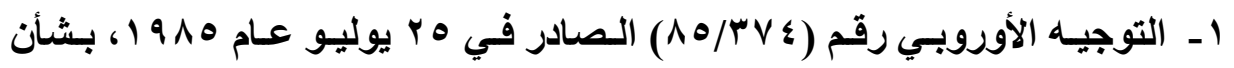

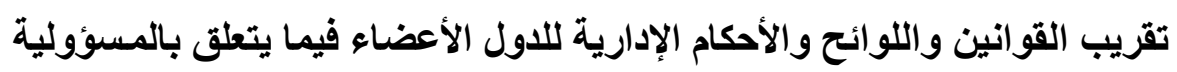

عن المنتجات المعيبة.

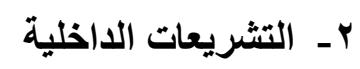

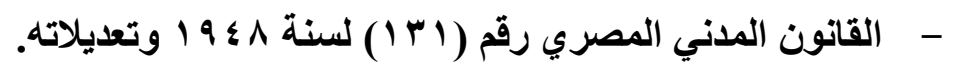

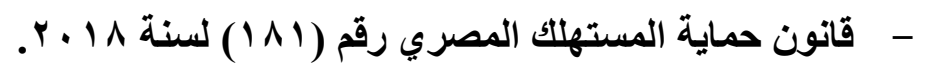

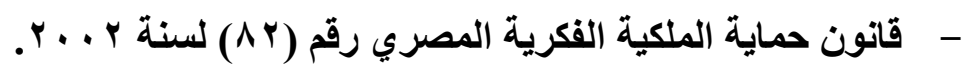

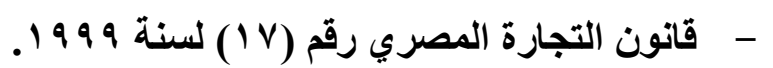

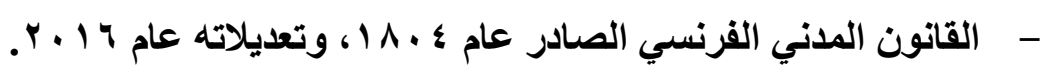

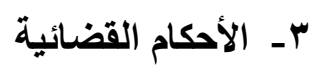

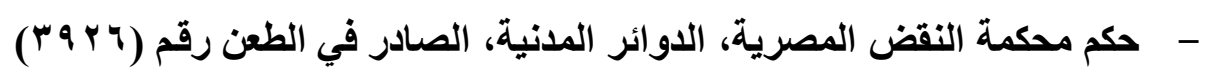

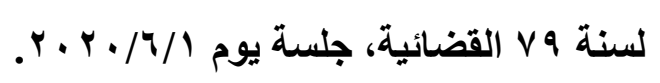

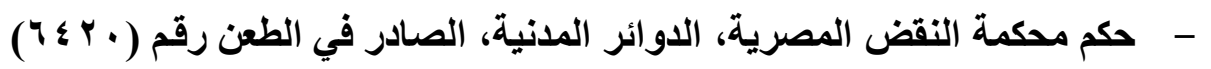

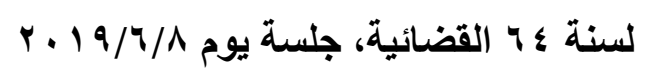

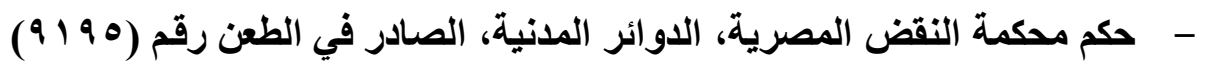

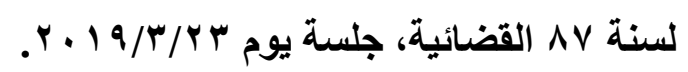

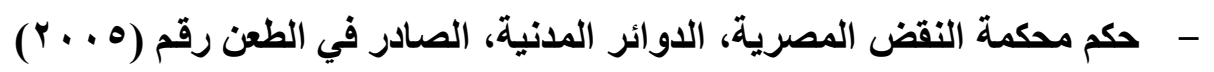

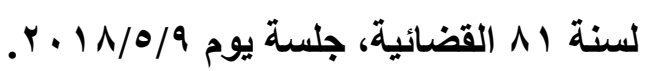




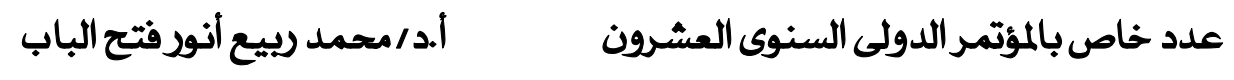

- Cass.comm. 5 avril 2018, no (13-21001), www.courdecassation.fr

- Cass.civ., 1ère, 3 mai 2018., no (16-26531), www.courdecassation.fr.

- Cass.civ., 1ère, 6 juillet 2017., Arrêt no 909 (16-77.217), www.courdecassation.fr.

$$
\text { ع - مواقع الانترنت }
$$

- https://ar.wikipedia.org/wiki كاريل تشـابيك

- https://www.wikipedia.org/wiki/Gakutensoku

- https://www.ar.wikipedia.org> صوفيا-روبوت

- $\quad$ https://al-ain.com/article/artificial-intelligence-robotshumans-century

- https://hrw.org/ar/news/2020/01/03/337058.

$$
\begin{aligned}
& \text { ثانيا: المراجع } \\
& \text { ا ـ المراجع باللغة العربية } \\
& \text { ـ د. السيد عيد نايل، "مصادر الالتزام غير الإرادية"، مكتبة كلية الحقوق - جامعة }
\end{aligned}
$$

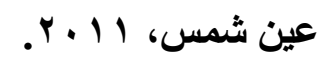

$$
\begin{aligned}
& \text { ـ ـ. حسام الدين كامـل الأهواني، " مـصادر الالتزام غير الإراديـة"، دار النهضة }
\end{aligned}
$$

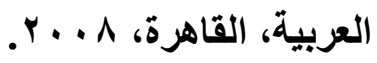


عدد خاص بالمؤتمر الدولى السنوى العشرون أ.د/محمد ربيع أنور فتح الباب

ـ د. طلبة وهبة خطاب، " النظرية العامة للالتزام - مصادر الالتزام غير الإرادية"،

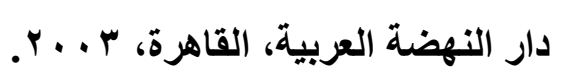

ـ ـ. عبد الهادي فوزي العوضي، المدخل لدراسة القانون المصري والعُمـاني، دار

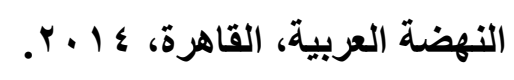

ـ د. محمد ربيع فتح الباب، د. مها رمضان بطيخ، المدخل لدراسـة القانون - نظريـة

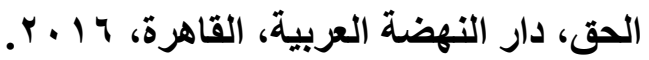

$$
\begin{aligned}
& \text { r ـ المراجع باللغات الأجنبية (الانجليزية ـ الفرنسية) }
\end{aligned}
$$

- BALKIN (J.M): "The path of Robotics law", California law Review, Vol. 6., June 2015,

- CALO (R.): “Artificial Intelligence Policy, A primer and Roadmap", University of California Davis Law Review, 2017, vol.51,

- CHONÉ (A.S.), et GLASER (P.H.): Résponsabilité Civile du Fait du Robot doné d' intelligence Artificielle: Faut-il créer une personnalité robotique?, $\mathrm{CCC}, \mathrm{n}^{\mathrm{O}} 1$, Janvier 2018.

- CINDY (V.R.): "Liability of robots: legal responsibility in cases of errors or malfunctioning", Ghent University, Faculty of Law, 2018 
عدد خاص بالمؤتمر الدولى السنوى العشرون أ.د/محمد ربيع أنور فتح الباب

- DOSQUET (E), DOSQUET (F.), MOYSAN (Y.), et SCIBETTA (F.): L' internet des objets et la data, L.G.D.J., 2018.

- El Kaakour (N.): “ L'intelligence artificielle et la responsabilité civile délictuelle"., Université Libanaise., Faculté de droit et des sciences politiques et administratives filière francophone., 2017.,

- Mendoza-Caminade (A.): “ Le droit confronté à l'IA des robots: vers l'émergence de nouveaux concepts juridiques?"., Recueil Dalloz., no 8., 2016

- NATHALE NEVEJANS: "Le Statut Juridique du Droit du Robot doit-il évoluer?", décembre 2019, https://lajauneetlarouge.com

- Schulpen (R.W.H.G): "Smart contracts in the NetherlandsA legal research regarding the use of smart contracts within Dutch contract law and legal framework"., Tilburg University., 2018., 